\title{
Combination fluticasone and salmeterol versus fixed dose combination budesonide and formoterol for chronic asthma in adults and children (Review)
}

\author{
Lasserson TJ, Cates CJ, Ferrara G, Casali L
}

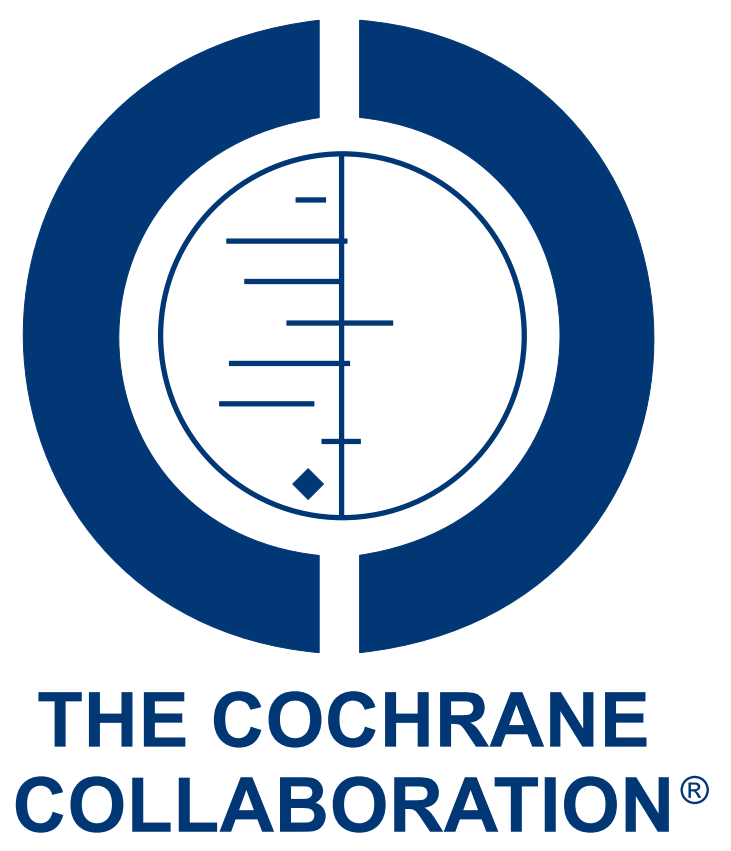

This is a reprint of a Cochrane review, prepared and maintained by The Cochrane Collaboration and published in The Cochrane Library 2010, Issue 3

http://www.thecochranelibrary.com

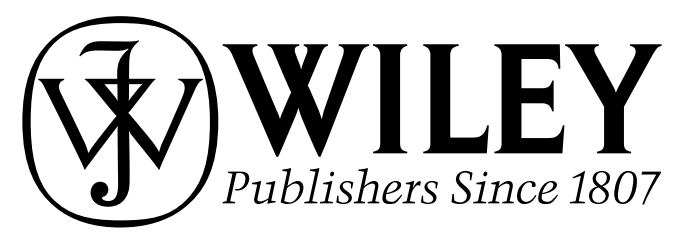

Combination fluticasone and salmeterol versus fixed dose combination budesonide and formoterol for chronic asthma in adults and children (Review)

Copyright (๑) 2010 The Cochrane Collaboration. Published by John Wiley \& Sons, Ltd. 
TABLE OF CONTENTS

HEADER . . . . . . . . . . . . . . . . . . . . . . . . . . . . . . . . . . . . . . . . . . 1

ABSTRACT . . . . . . . . . . . . . . . . . . . . . . . . . . . . . . . . . . . . . . . . . . . . 1

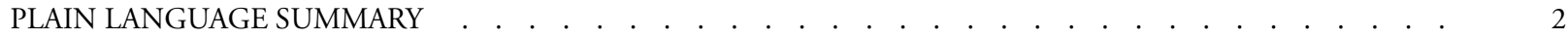

SUMMARY OF FINDINGS FOR THE MAIN COMPARISON . . . . . . . . . . . . . . . . . . . . . . . 2

BACKGROUND . . . . . . . . . . . . . . . . . . . . . . . . . . . . . . . . . . . . 5

OBJECTIVES . . . . . . . . . . . . . . . . . . . . . . . . . . . . . . . . . . . . . . . . . . 5

METHODS . . . . . . . . . . . . . . . . . . . . . . . . . . . . . . . . . . . . . . 5

RESULTS . . . . . . . . . . . . . . . . . . . . . . . . . . . . . . . . . . . . . . . 47

Figure 1. . . . . . . . . . . . . . . . . . . . . . . . . . . . . . . . . . . . . . 8

Figure 2. . . . . . . . . . . . . . . . . . . . . . . . . . . . . . . . . . . . . . 10

Figure 3. . . . . . . . . . . . . . . . . . . . . . . . . . . . . . . . . . . . . . 11

Figure $4 . \quad$. . . . . . . . . . . . . . . . . . . . . . . . . . . . . . . . . . . . . 12

Figure 5. . . . . . . . . . . . . . . . . . . . . . . . . . . . . . . . . . . . . . 12

Figure 6. . . . . . . . . . . . . . . . . . . . . . . . . . . . . . . . . . . . . . 13

DISCUSSION . . . . . . . . . . . . . . . . . . . . . . . . . . . . . . . . . . . . . 13

AUTHORS' CONCLUSIONS . . . . . . . . . . . . . . . . . . . . . . . . . . . . . . . . . . . . . . 14

ACKNOWLEDGEMENTS . . . . . . . . . . . . . . . . . . . . . . . . . . . . . . . . 14

REFERENCES . . . . . . . . . . . . . . . . . . . . . . . . . . . . . . . . . . . . . 15

CHARACTERISTICS OF STUDIES . . . . . . . . . . . . . . . . . . . . . . . . . . . . . . . . . $\quad 20$

DATA AND ANALYSES . . . . . . . . . . . . . . . . . . . . . . . . . . . . . . . . . . . . . . . . . . . . . . . . . . 30

Analysis 1.1. Comparison 1 Combination fluticasone/salmeterol versus budesonide/formoterol, Outcome 1 Participants experiencing exacerbations requiring oral steroid treatment. . . . . . . . . . . . . . . . . . . . . 31

Analysis 1.2. Comparison 1 Combination fluticasone/salmeterol versus budesonide/formoterol, Outcome 2 Participants experiencing exacerbations requiring admission to hospital. . . . . . . . . . . . . . . . . . . . . . . . . . 31

Analysis 1.3. Comparison 1 Combination fluticasone/salmeterol versus budesonide/formoterol, Outcome 3 Asthma-related serious adverse event. . . . . . . . . . . . . . . . . . . . . . . . . . . . . . . . 32

Analysis 1.4. Comparison 1 Combination fluticasone/salmeterol versus budesonide/formoterol, Outcome 4 Participants experiencing exacerbations requiring $\mathrm{ED}$ visit/hospitalisation. . . . . . . . . . . . . . . . . . . . . .

Analysis 1.5. Comparison 1 Combination fluticasone/salmeterol versus budesonide/formoterol, Outcome 5 Change in FEV1.

Analysis 1.6. Comparison 1 Combination fluticasone/salmeterol versus budesonide/formoterol, Outcome 6 Change in FEV1 predicted (\%). . . . . . . . . . . . . . . . . . . . . . . . . . . . . . . .

Analysis 1.7. Comparison 1 Combination fluticasone/salmeterol versus budesonide/formoterol, Outcome 7 Change in am PEF.

Analysis 1.8. Comparison 1 Combination fluticasone/salmeterol versus budesonide/formoterol, Outcome 8 Change in pm PEF.

Analysis 1.9. Comparison 1 Combination fluticasone/salmeterol versus budesonide/formoterol, Outcome 9 Change in daytime symptoms.

Analysis 1.10. Comparison 1 Combination fluticasone/salmeterol versus budesonide/formoterol, Outcome 10 Change in symptom-free days. . . . . . . . . . . . . . . . . . . . . . . . . . . . . . . . . 36

Analysis 1.11. Comparison 1 Combination fluticasone/salmeterol versus budesonide/formoterol, Outcome 11 Change in nocturnal awakenings. . . . . . . . . . . . . . . . . . . . . . . . . . . . . . . . 37

Analysis 1.12. Comparison 1 Combination fluticasone/salmeterol versus budesonide/formoterol, Outcome 12 Change in rescue medication use. . . . . . . . . . . . . . . . . . . . . . . . . . . . . . . . . . . . . . . . . . . $\quad 37$

Analysis 1.13. Comparison 1 Combination fluticasone/salmeterol versus budesonide/formoterol, Outcome 13 Withdrawals. . . . . . . . . . . . . . . . . . . . . . . . . . . . . . . . . . . 38

Analysis 1.14. Comparison 1 Combination fluticasone/salmeterol versus budesonide/formoterol, Outcome 14 Withdrawals (adverse events). . . . . . . . . . . . . . . . . . . . . . . . . . . . . . . . . . 39

Analysis 1.15. Comparison 1 Combination fluticasone/salmeterol versus budesonide/formoterol, Outcome 15 Withdrawals (lack of efficacy). . . . . . . . . . . . . . . . . . . . . . . . . . . . . . . . . . . . . . . . . 39

Combination fluticasone and salmeterol versus fixed dose combination budesonide and formoterol for chronic asthma in adults and children (Review)

Copyright @ 2010 The Cochrane Collaboration. Published by John Wiley \& Sons, Ltd. 
Analysis 1.16. Comparison 1 Combination fluticasone/salmeterol versus budesonide/formoterol, Outcome 16 Adverse events. . . . . . . . . . . . . . . . . . . . . . . . . . . . . . . . . . . . .

Analysis 1.17. Comparison 1 Combination fluticasone/salmeterol versus budesonide/formoterol, Outcome 17 Headache. Analysis 1.18. Comparison 1 Combination fluticasone/salmeterol versus budesonide/formoterol, Outcome 18 Candidiasis. . . . . . . . . . . . . . . . . . . . . . . . . . . . . . . . . . .

Analysis 1.19. Comparison 1 Combination fluticasone/salmeterol versus budesonide/formoterol, Outcome 19 Dysphonia.

Analysis 1.20. Comparison 1 Combination fluticasone/salmeterol versus budesonide/formoterol, Outcome 20 Upper respiratory tract infection. . . . . . . . . . . . . . . . . . . . . . . . . . . . . .

Analysis 1.21. Comparison 1 Combination fluticasone/salmeterol versus budesonide/formoterol, Outcome 21 Rhinitis.

Analysis 1.22. Comparison 1 Combination fluticasone/salmeterol versus budesonide/formoterol, Outcome 22 Throat irritation. . . . . . . . . . . . . . . . . . . . . . . . . . . .

Analysis 1.23. Comparison 1 Combination fluticasone/salmeterol versus budesonide/formoterol, Outcome 23 Cough.

Analysis 1.24. Comparison 1 Combination fluticasone/salmeterol versus budesonide/formoterol, Outcome 24 Tremor.

WHAT'S NEW . . . . . . . . . . . . . . . . . . . . . . . . . . . . . . . . . . . . . .

HISTORY

CONTRIBUTIONS OF AUTHORS

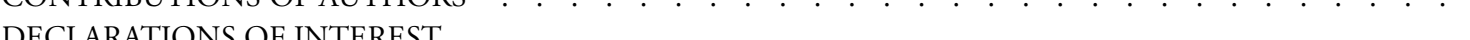

SOURCES OF SUPPORT

DIFFERENCES BETWEEN PROTOCOL AND REVIEW . . . . . . . . . . . . . . . . . . . . . . . . . . .

NOTES . . . . . . . . . . . . . . . . . . . . . . . . . . . . . . . . . . . . . . . .

INDEX TERMS 
[Intervention Review]

\title{
Combination fluticasone and salmeterol versus fixed dose combination budesonide and formoterol for chronic asthma in adults and children
}

\author{
Toby J Lasserson ${ }^{1}$, Christopher J Cates ${ }^{1}$, Giovanni Ferrara ${ }^{2}$, Lucio Casali ${ }^{3}$ \\ ${ }^{1}$ Community Health Sciences, St George's, University of London, London, UK. ${ }^{2}$ Section of Respiratory Diseases, Department of \\ Internal Medicine, Unversity of Perugia, Terni, Italy. ${ }^{3}$ Internal Medicine, University of Perugia, Terni, Italy
}

Contact address: Toby J Lasserson, Community Health Sciences, St George's, University of London, Cranmer Terrace, London, SW17 0RE, UK. tlassers@sgul.ac.uk. tlasserson@cochrane.org.

Editorial group: Cochrane Airways Group.

Publication status and date: New search for studies and content updated (no change to conclusions), published in Issue 3, 2010.

Review content assessed as up-to-date: 20 January 2010.

Citation: Lasserson TJ, Cates CJ, Ferrara G, Casali L. Combination fluticasone and salmeterol versus fixed dose combination budesonide and formoterol for chronic asthma in adults and children. Cochrane Database of Systematic Reviews 2008, Issue 1. Art. No.: CD004106. DOI: 10.1002/14651858.CD004106.pub3.

Copyright (C) 2010 The Cochrane Collaboration. Published by John Wiley \& Sons, Ltd.

\begin{abstract}
A B S T R A C T
Background

Combination therapies are frequently recommended as maintenance therapy for people with asthma, whose disease is not adequately controlled with inhaled steroids. Fluticasone/salmeterol (FP/SAL) and budesonide/formoterol (BUD/F) have been assessed against their respective monocomponents, but there is a need to compare these two therapies on a head-to-head basis.
\end{abstract}

Objectives

To estimate the relative effects of fluticasone/salmeterol and budesonide/formoterol in terms of asthma control, safety and lung function.

Search strategy

We searched the Cochrane Airways Group register of trials with prespecified terms. We performed additional hand searching of manufacturers' web sites and online trial registries. Searches are current to May 2009.

Selection criteria

Randomised studies comparing fixed dose FP/SAL and BUD/F were eligible, for a minimum of 12 weeks. Crossover studies were excluded. Our primary outcomes were: i) exacerbations requiring oral steroid bursts, ii) hospital admission and iii) serious adverse events.

Data collection and analysis

Two authors independently assessed studies for inclusion in the review. We combined continuous data outcomes with a mean difference (MD), and dichotomous data outcomes with an odds ratio (OR).

Combination fluticasone and salmeterol versus fixed dose combination budesonide and formoterol for chronic asthma in adults and I children (Review)

Copyright @ 2010 The Cochrane Collaboration. Published by John Wiley \& Sons, Ltd. 


\section{Main results}

Five studies met the review entry criteria (5537 adults). Primary outcomes: The odds of an exacerbation requiring oral steroids did not differ significantly between treatments (OR $0.89 ; 95 \%$ CI 0.74 to 1.07 , four studies, 4949 adults). The odds of an exacerbation leading hospital admission were also not significantly different (OR 1.29; 95\% CI 0.68 to 2.47, four studies, 4879 participants). The odds of serious adverse events did not differ significantly between treatments (OR 1.47; 95\% CI 0.75, 2.86, three studies, 4054 participants). Secondary outcomes: Lung function outcomes, symptoms, rescue medication, exacerbations leading ED visit/hospital admission and adverse events did not differ statistically between treatments.

\section{Authors' conclusions}

The evidence in this review indicates that differences in the requirement for oral steroids and hospital admission between BUD/F and FP/SAL do not reach statistical significance. However, the confidence intervals do not exclude clinically important differences between treatments in reducing exacerbations or causing adverse events. The width of the confidence intervals for the primary outcomes justify further trials in order to better determine the relative effects of these drug combinations. Although this review sought to assess the effects of these drugs in both adults and children, no trials were identified in the under-12s and research in this area is of a high priority.

\section{PLAIN LANGUAGE SUMMARY}

The effects of different combinations of inhaled steroids and long-acting beta-agonists for chronic asthma

Persistent asthma often requires the combination of inhaled corticosteroids (ICS) and long-acting beta2-agonists (LABA). This systematic review examined randomised controlled trials comparing two commonly available combinations administered at fixed dose with a single inhaler, fluticasone/salmeterol (FP/SAL) and budesonide/formoterol (BUD/F). We found that the number of adults who required treatment with oral steroids or admission to hospital was similar between the treatments, but that additional trials would improve the precision of our estimates. No statistical differences were found for pulmonary function, rescue medication use and adverse events. Well-designed studies on these questions on different types of patients are needed to confirm and to better explain these findings. In particular studies which assess the effects of these therapies in children are of a high priority. 


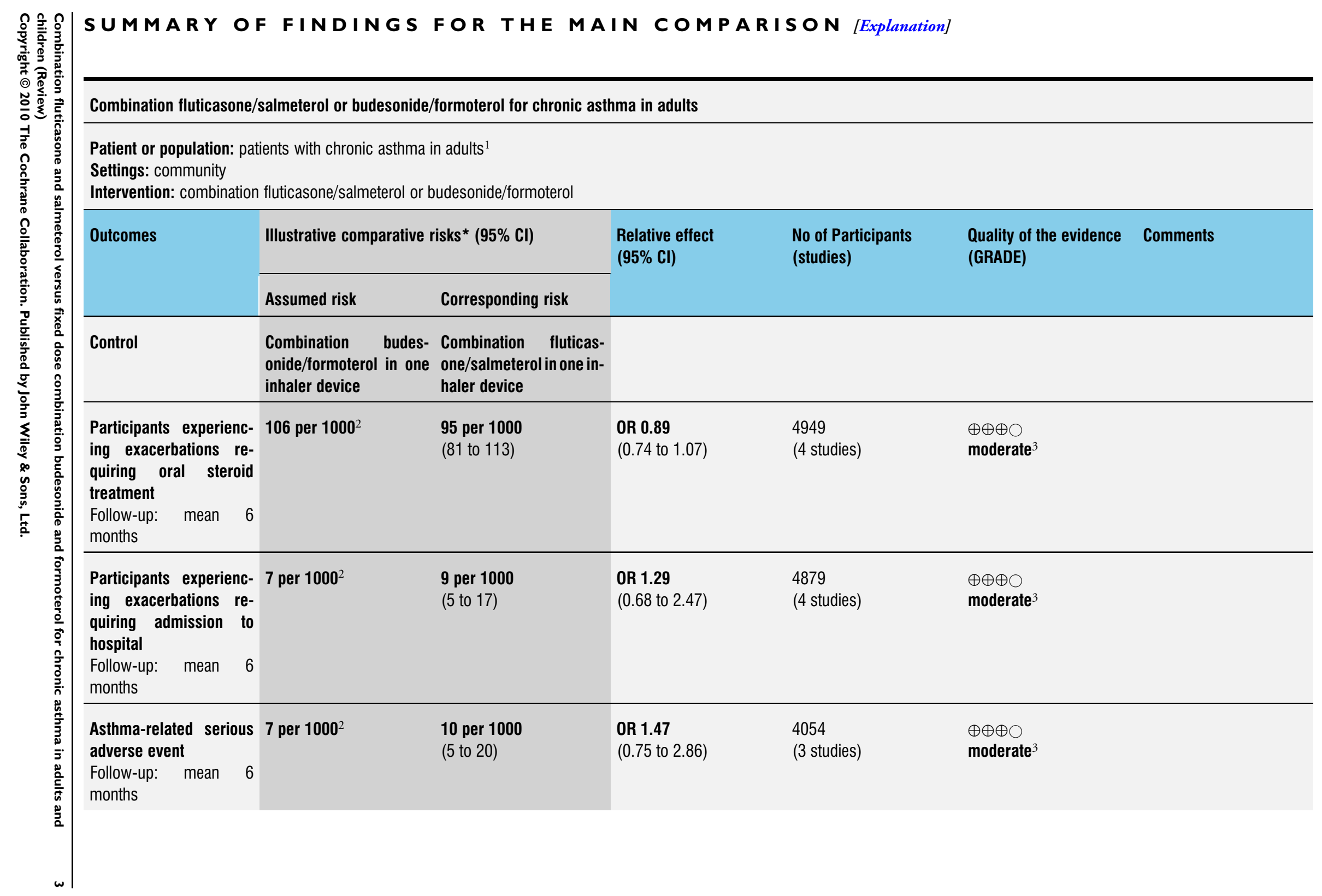


The basis for the assumed risk (e.g. the median control group risk across studies) is provided in footnotes. The corresponding risk (and its $95 \%$ confidence interval) is based on the assumed risk in the comparison group and the relative effect of the intervention (and its $95 \% \mathrm{Cl}$ ).

Cl: Confidence interval; OR: Odds ratio;

GRADE Working Group grades of evidence

High quality: Further research is very unlikely to change our confidence in the estimate of effect.

Moderate quality: Further research is likely to have an important impact on our confidence in the estimate of effect and may change the estimate.

Low quality: Further research is very likely to have an important impact on our confidence in the estimate of effect and is likely to change the estimate.

Very low quality: We are very uncertain about the estimate.

1. No studies have been found in children. The findings of this review are only applicable to adults.

2. The mean event rate in the BDF arms of the trials was used to calculate the assumed risk.

3. The confidence interval is wide and could change with the addition of new evidence. 


\section{B A C K G R O U N D}

Asthma is a chronic inflammatory disease of the airways, and antiinflammatory treatment is a cornerstone of asthma therapy. Treatment with inhaled corticosteroids (ICS) improves lung function and reduces asthma symptoms in mild persistent asthmatic patients (Adams 2008). Many patients remain symptomatic despite using optimal doses of ICS. However, patients do benefit by the addition of an inhaled long-acting beta2-agonist (LABA). This approach further improves lung function and quality of life in patients with moderate to severe persistent asthma (Ni Chroinin 2005).

The principal advantage of combining ICS and LABA in one inhaler is the simultaneous delivery of two effective inhaled therapies. This may lead users to better adhere to dosing regimens, especially given concerns over the use of LABA therapy without a regular background steroid (Walters 2007). Clinicians and people with asthma are faced with a choice between two treatments as maintenance treatment of asthma: the ICS fluticasone and LABA salmeterol preparation marketed as 'Seretide', 'Advair' or 'Viani', and the ICS budesonide and LABA formoterol preparation marketed as 'Symbicort'.

There is some uncertainty as to which particular combination may be suitable. Previous assessments have considered the addition of any LABA to any ICS when the dose of ICS is increased or when the study drugs are titrated according to symptoms (Greenstone 2005; Gibson 2005). Although the LABAs commonly used in combination preparations have a similar duration of effect of around 12 hours or more, salmeterol and formoterol also have differing pharmacological properties. The onset of action of formoterol is faster than that of salmeterol (Palmqvist 1997; van Noord 1996) and has as rapid an onset of action as salbutamol in asthma (Cazzola 2002). Some differences exist also between fluticasone and budesonide despite the shared anti-inflammatory effect (Adams 2007), and so a systematic exploration of the relative efficacy of these different drug combinations is justified.

\section{O B JE C T I VES}

To compare the combinations of salmeterol/fluticasone and budesonide/formoterol in single inhaler devices in chronic asthma in terms of asthma control, safety and lung function.

\section{METHODS}

\section{Criteria for considering studies for this review}

Types of studies
Randomised, clinical trials comparing single inhaler devices containing combination fluticasone and salmeterol versus budesonide and formoterol. Only studies with a parallel design were eligible as the minimum washout period of inhaled steroids has not been adequately established.

\section{Types of participants}

Adults and children with a diagnosis of chronic asthma. We accepted trialist-defined asthma. Any severity of asthma and patients on any co-intervention were eligible (as long as the co-interventions were not part of the randomised treatment) but studies on acute asthma carried out in emergency departments were excluded.

\section{Types of interventions}

The preparations considered by this review were the combination of the inhaled steroid fluticasone and long-acting beta-agonist salmeterol (FP/SAL) against the inhaled steroid budesonide and long-acting beta-agonist formoterol (BUD/F) in one inhaler device. We included studies which assessed the combination of drugs in either metered dose inhalers (MDI) or dry powder inhaler (DPI). We considered fixed dose comparisons between these preparations and we have excluded studies assessing the efficacy and safety of different dosing strategies of budesonide/formoterol ('single inhaler therapy' or 'adjustable maintenance dosing') with fixed dose fluticasone/salmeterol. Studies had a minimum duration of 12 weeks in order to meet the entry criteria of this review.

\section{Types of outcome measures}

\section{Primary outcomes}

1. Exacerbations of asthma requiring oral steroids

2. Exacerbations of asthma requiring hospital admission

3. Serious adverse events (including asthma-related death and intubation)

\section{Secondary outcomes}

1. Exacerbations leading to ED visit/admission to hospital

2. Diary card morning and evening peak expiratory flow (PEF)

3. Clinic spirometry (FEV1, clinic PEF, FVC)

4. Rescue medication use

5. Symptoms

6. Quality of life

7. Adverse events

8. Study withdrawal 


\section{Search methods for identification of studies}

Trials were identified using the Cochrane Airways Group Specialised Register of trials, which is derived from systematic searches of bibliographic databases including the Cochrane Central Register of Controlled Trials (CENTRAL), MEDLINE, EMBASE, CINAHL, AMED and PsycINFO, and hand searching of respiratory journals and meeting abstracts. All records in the Specialised Register coded as 'asthma' were searched using the following terms:

("single inhaler" or symbicort or seretide or advair or viani) or ((steroid* or corticosteroid* or ICS or fluticasone or FP or Flixotide or budesonide or BUD or Pulmicort) and ("long acting beta agonist*" or "*beta-agonist*" or LABA* or salmeterol or serevent or formoterol or eformoterol or oxis or foradil))

Reference lists of all primary studies and review articles were reviewed for additional references. Authors of identified randomised trials were asked about knowledge of other published and unpublished studies. Manufacturers of combination single inhaler devices were contacted regarding other published and unpublished studies.

We contacted trialists and manufacturers in order to obtain unreported data and to establish whether other unpublished or ongoing studies are available for assessment. We undertook additional hand searching of clinical trial web sites (www.clinicalstudyresults.org; www.clinicaltrials.gov; www.fda.gov) and the clinical trial web sites of manufacturers (www.ctr.gsk.co.uk; www.astrazenecaclinicaltrials.com). Searches are current to May 2009.

\section{Data collection and analysis}

\section{Selection of studies}

Following electronic literature searches, two review authors independently selected articles on the basis of title and/or abstract for full text scrutiny. The authors agreed a list of articles which were retrieved, and they subsequently assessed each reference to determine whether it met the review eligibility criteria.

\section{Data extraction and management}

One author (TJL) extracted information from each study for the following characteristics:

Design (description of randomisation, blinding, number of study centres and location, number of study withdrawals).

Participants (N, mean age, age range of the study, gender ratio, baseline lung function, $\%$ on maintenance ICS or ICS/LABA combination \& average daily dose of steroid (BDP equivalent), entry criteria).
Intervention (type and dose of component ICS and LABA, dosing schedule, inhaler device, study duration $\&$ run-in)

Outcomes (type of outcome analysis, outcomes analysed, numerical data)

This information was double-checked by a second author (GF \& CJC).

\section{Assessment of risk of bias in included studies}

We assessed study quality according to whether studies met the following pre-specified quality criteria (as yes, no or unclear, Handbook 2005):

1. Allocation generation - was sequence generation unpredictable?

2. Allocation concealment - were steps taken to prevent foreknowledge of treatment group assignment?

3. Blinding - were the treatments known to the patients, investigators and those assessing outcomes?

4. Withdrawal - were all participants who entered the study accounted for, and was the analysis likely to be biased by the handling of dropouts? This was considered in relation to the outcomes of oral steroid requirement and hospital admission.

5. Selective reporting - was there evidence of unreported outcome data in the trial report(s)?

6. Other bias - was the study free of other types of bias? Additional information were sought on outcomes that were partially reported from the study sponsors.

\section{Dealing with missing data}

We contacted study sponsors for additional data which we required for our primary outcomes of oral steroid-treated exacerbations, and exacerbations leading to hospital admission.

\section{Assessment of heterogeneity}

We measured statistical variation between studies by the I square statistic (Higgins 2003). Where this exceeded $20 \%$ we also applied random effects modelling to assess whether assuming a distribution of related true effects (rather than a fixed true effect) altered the pooled effect estimate.

\section{Data synthesis}

Data were combined with RevMan 5, using a a fixed effect odds ratio for dichotomous variables, and a fixed effect mean difference (calculated as either a weighted mean difference or a mean difference weighted by generic inverse variance) for continuous data variables. For the primary outcome of exacerbations we calculated NNT(benefit) for the different levels of risk as represented by control group event rates (www.nntonline.net), in order to express the number of patients needed to be treated with intervention to prevent one event from occurring. 
We generated a summary of findings table for the primary outcomes in the review (exacerbations requiring oral steroids, exacerbations leading to hospital admission, and serious adverse events). We generated the table with GRADEpro software.

\section{Subgroup analysis and investigation of heterogeneity}

We intended to subgroup data from adults, adolescents and children in subgroups. Adult studies were considered as those which recruited participants from 18 upwards. Adult and adolescent studies were considered as those which recruited participants from 12 upwards. We considered participants in studies where the upper age limit was 12 years as children, and in studies where the upper age limit was 18 years as children and adolescents. Despite this categorisation we did not identify any studies performed in children less than 12 years of age.

Subgroup analyses was performed based on the severity of asthma as assessed according to international guidelines (GINA: controlled, partly controlled, uncontrolled), and trials on patients using oral steroid treatment were considered separately. We restricted subgroup analysis to our primary outcomes.

\section{Sensitivity analysis}

Sensitivity analysis was conducted on the risk of bias, where the predefined quality criteria of randomisation, blinding and withdrawal are met. We also considered the impact of dosing and in- haler devices for both interventions. Funnel plots were inspected to assess the presence of publication bias.

\section{RE S U L T S}

\section{Description of studies}

See: Characteristics of included studies; Characteristics of excluded studies.

\section{Results of the search}

From 747 references identified by literature searches up to May 2009 , five studies (26 citations) met the entry criteria of the review. Of these, four are full-text publications, and one is available as a download from a manufacturer's web site (SAM40048).

Details of the literature search and study assessment processes for the 2009 literature search are provided in Figure 1. Four studies (reported in five separate references) considered for this update failed to meet the eligibility criteria (Adachi 2008; Ambrose 2007; Bleecker 2007; Hampel 2007, see Characteristics of excluded studies). A further six references from this search were identified as additional publications from two included studies (COMPASS; Busse 2008), and one excluded study (AHEAD). 
Figure I. Literature flow diagram for the review.

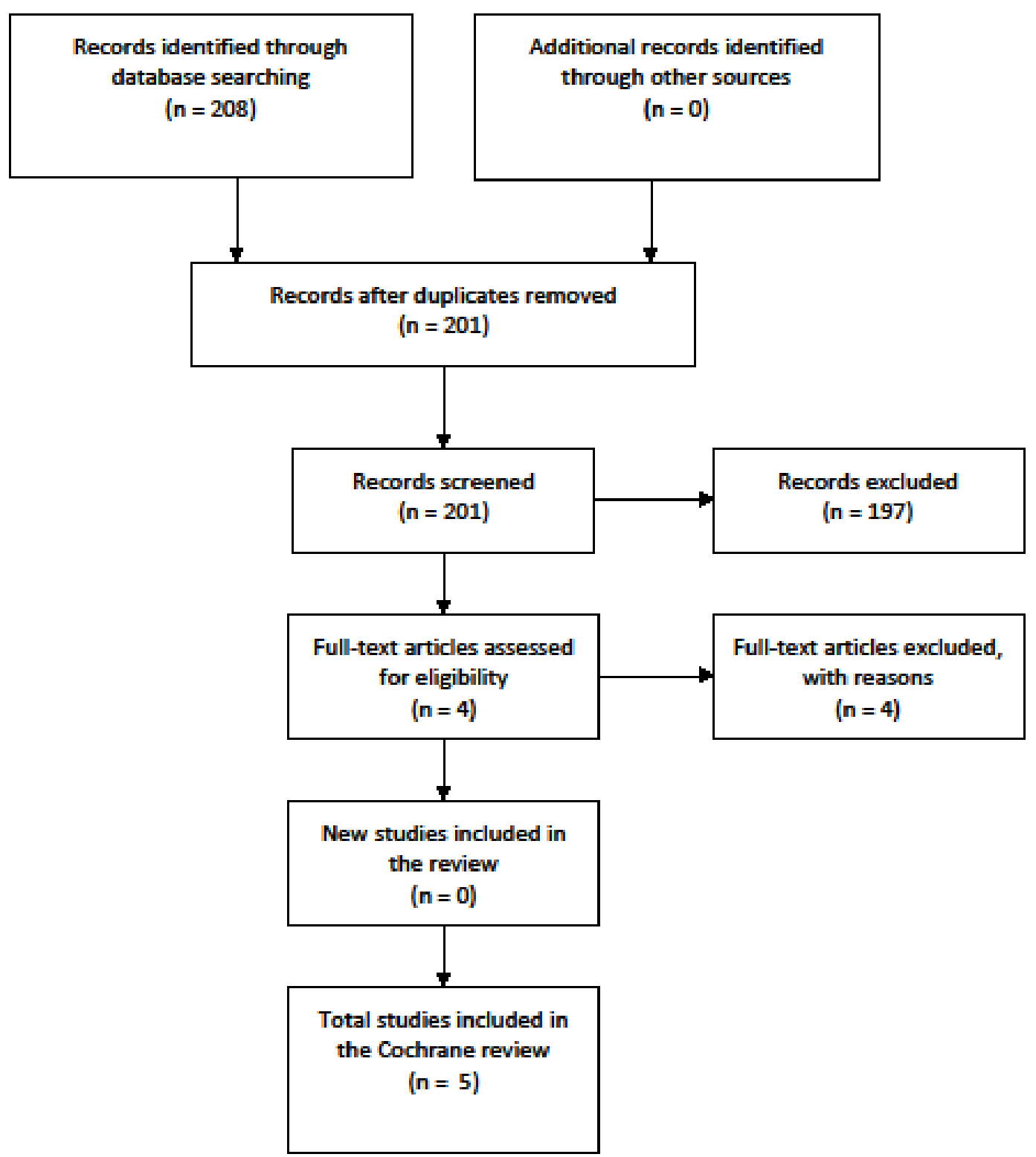

Combination fluticasone and salmeterol versus fixed dose combination budesonide and formoterol for chronic asthma in adults and 


\section{Included studies}

\section{Population}

5537 adult and adolescent participants were recruited to the studies. The studies required participants to have a history of chronic asthma, treated with maintenance inhaled corticosteroids at moderate to high doses prior to study entry. In the five studies, participants had to be stable for one month before the run-in period. Once in the run-in phase, participants were further required to demonstrate the need for frequent reliever inhaler use. On the basis of these characteristics we adjudged the trial populations to be partly controlled, since the requirement for relief medication was in addition to chronically applied inhaled steroids (GINA). The severity of airway obstruction varied between the trials, with the participants with the lowest percentage predicted of FEV1 recruited to SAM40048 (65\%), Busse 2008; EXCEL and COMPASS recruiting participants with moderate airway obstruction (79\%, 79\% and 73\% respectively), and participants with milder obstruction represented in Aalbers 2004 (84\%).

\section{Interventions \& comparisons}

Converting the inhaled steroid load to BDP equivalent indicated that the trials assessed high doses of inhaled steroids in both FP/ $\mathrm{SAL}$ and $\mathrm{BUD} / \mathrm{F}$ groups, although FP/SAL was higher in BDP equivalence terms than BUD/F (1000 versus $400-800 \mathrm{mcg} /$ day). All doses were given twice daily via different inhalers (Diskus and Turbohaler for FP/SAL and BUD/F respectively). Two studies were open label (Aalbers 2004; Busse 2008). In all studies the dose of FP/SAL was $500 / 100 \mathrm{mcg} /$ day, and that of BUD/F was 400$800 / 12-24 \mathrm{mcg} /$ day.

Concomitant use of reliever medication was permitted in all four studies; terbutaline in COMPASS, salbutamol in Busse 2008 and EXCEL, and terbutaline or salbutamol as preferred in Aalbers 2004. In SAM 40048 the reliever medication was not reported.

\section{Outcomes}

Four trials measured exacerbations as oral steroid and hospitalisations (Aalbers 2004; Busse 2008; EXCEL; COMPASS), and also gave numerical data for serious adverse events. All studies reported lung function measurements. Data on admission to hospital were made available to the review authors on request from GSK and AZ for Aalbers 2004; COMPASS; EXCEL. We were informed verbally that exacerbations were not collected in a way that was suitable for us to use in our review in SAM40048.

\section{Excluded studies}

A total of 19 studies failed to meet the review eligibility criteria. The reasons for their exclusion are listed in Characteristics of excluded studies.

\section{Risk of bias in included studies}

See Figure 2 and Figure 3 for summaries of risk of bias. Additional details on items are provided in Characteristics of included studies. Generally the studies were well designed although reliable assessment of selective reporting could not be ascertained. Primary outcome data were either reported in the studies or made available to the authors on request. 
Figure 2. Risk of bias summary: review authors' judgments about each risk of bias item for each included study.

\begin{tabular}{|c|c|c|c|c|c|c|c|}
\hline & 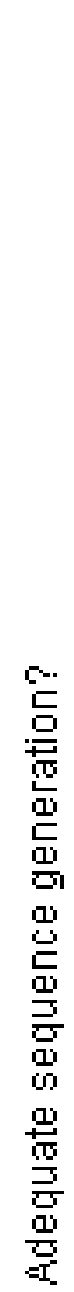 & 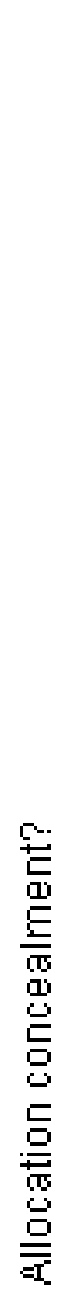 & 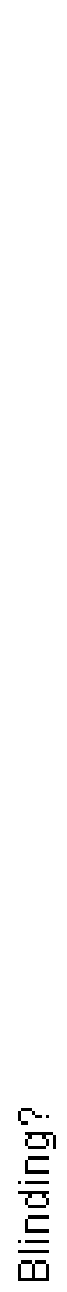 & 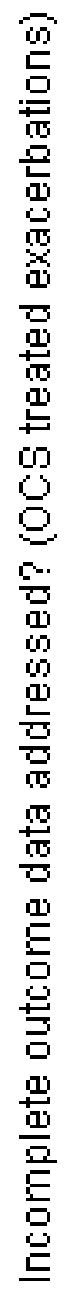 & 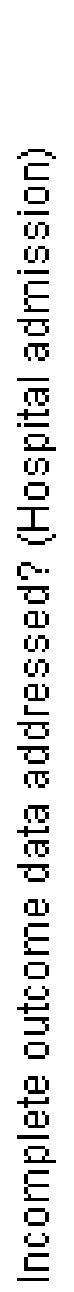 & 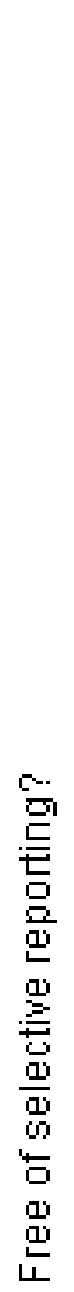 & 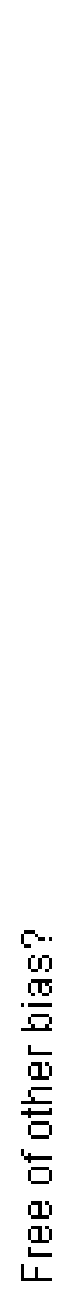 \\
\hline \multirow[t]{2}{*}{ Aalbers 2004} & + & & 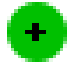 & $?$ & $?$ & $?$ & \\
\hline & + & 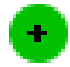 & & $?$ & $?$ & $?$ & 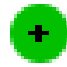 \\
\hline COMPASS & + & & & $?$ & $?$ & + & + \\
\hline EXCEL & + & $\uparrow$ & . & $?$ & $?$ & $?$ & + \\
\hline SAM 40048 & $?$ & $?$ & + & $?$ & $?$ & $?$ & + \\
\hline
\end{tabular}

Combination fluticasone and salmeterol versus fixed dose combination budesonide and formoterol for chronic asthma in adults and 
Figure 3. Risk of bias graph: review authors' judgments about each risk of bias item presented as percentages across all included studies.

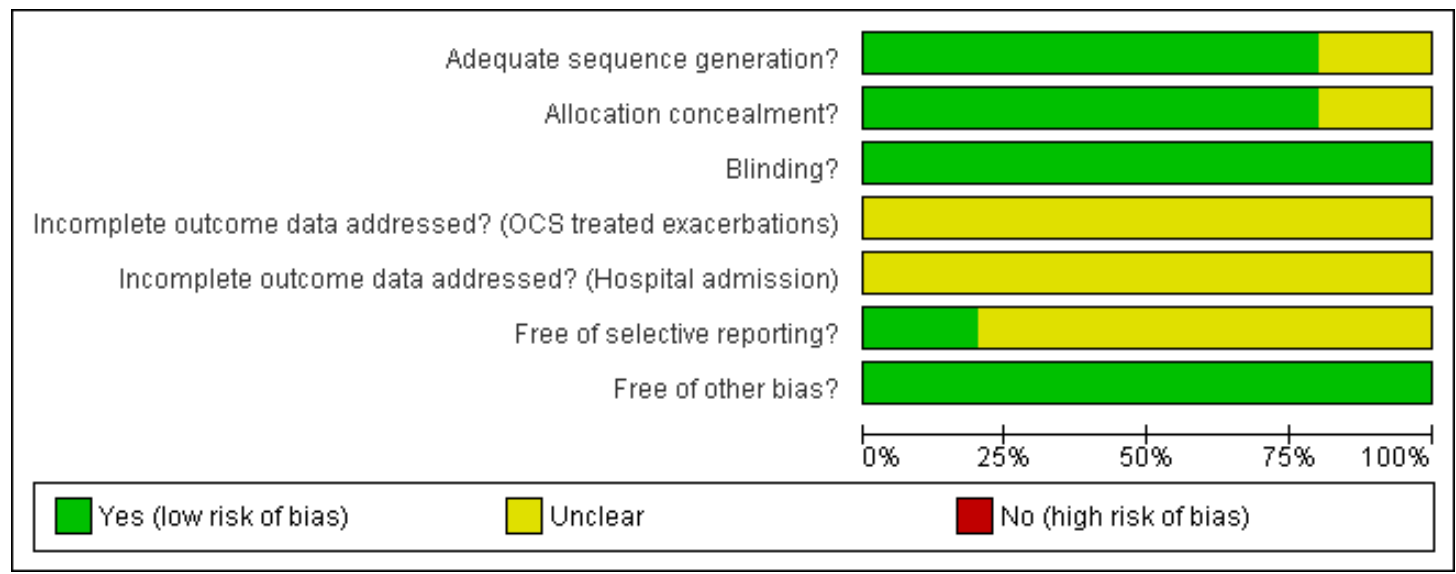

\section{Allocation}

The four studies available as full-text articles reported computergenerated randomisation sequences, with adequate concealment of treatment group allocation. Demographic characteristics of all four of the studies indicated that treatment groups were well balanced. Details on SAM40048 were not adequately reported for us to establish the appropriateness of the concealment of allocation.

\section{Blinding}

We used outcome data from an open label phase in two studies (Aalbers 2004; Busse 2008). The remaining studies used a doubledummy design to control for awareness of treatment group allocation. Blinding of outcome assessment was not reported in the studies.

\section{Incomplete outcome data}

Intention to treat analyses were used in all of the studies based on the population randomised, but explicit description of follow-up and handling of missing data were not provided.

\section{Selective reporting}

We needed to contact the study sponsors of Aalbers 2004; COMPASS for data pertaining to our primary outcomes of exacerbations (AstraZeneca). The sponsors of EXCEL confirmed data on the primary outcomes, and made available data for exacerbations leading to ED visits and admission to hospital (see Published notes).

\section{Effects of interventions}

See: Summary of findings for the main comparison Combination fluticasone/salmeterol or budesonide/formoterol for chronic asthma in adults

Using published data and unpublished data obtained through correspondence with manufacturers, we included four of the five eligible trials in the three co-primary outcomes representing $88 \%$ of randomised participants.

\section{FP/SAL 500// $00 \mathrm{mcg} / \mathrm{d}$ versus BUD/F 400-800// 2-24 $\mathrm{mcg} / \mathrm{d}$}

The comparisons are presented such that a reduction in the mean difference greater than 0 , or an odds ratio of less than one represent a lowering for the FP/SAL group compared to the BUD/F group (the associated confidence intervals and $\mathrm{P}$ value indicate the statistical significance of this). In view of the absence of studies in children, the evidence we have relates to adults.

\section{Primary outcomes}

Exacerbations \& asthma related serious adverse events 
There was no significant difference in the risk of experiencing an exacerbation requiring oral-steroid treatment (four studies, OR $0.89 ; 95 \%$ CI 0.74 to $1.07, \mathrm{~N}=4515$ Figure 4 ).

Figure 4. Forest plot of comparison: I Combination fluticasone/salmeterol versus budesonide/formoterol, outcome: I.I Participants experiencing exacerbations requiring oral steroid treatment.

\begin{tabular}{|c|c|c|c|c|c|c|c|}
\hline \multirow[b]{2}{*}{ Stucty or Subgroup } & \multicolumn{2}{|c|}{ FPISAL } & \multicolumn{2}{|c|}{ BUDIF } & \multirow[b]{2}{*}{ Weight } & \multirow{2}{*}{$\begin{array}{l}\text { Odds Ratio } \\
\text { M-H, Fixed, 95\% Cl }\end{array}$} & \multirow{2}{*}{$\begin{array}{l}\text { Odds Ratio } \\
\text { M-H, Fixed, 95\% Cl }\end{array}$} \\
\hline & Events & Total & Events & Total & & & \\
\hline Aalbers 2004 & 30 & 219 & 33 & 215 & $12.2 \%$ & $0.88[0.51,1.49]$ & - \\
\hline Busse 2008 & 37 & 404 & 37 & 422 & $13.9 \%$ & $1.05[0.65,1.69]$ & \\
\hline COMPASS & 109 & 1199 & 108 & 1099 & $43.5 \%$ & $0.92[0.69,1.21]$ & \\
\hline EXCEL & 63 & 694 & 79 & 697 & $30.4 \%$ & $0.78[0.55,1.11]$ & $\rightarrow$ \\
\hline Total $(95 \% \mathrm{Cl})$ & & 2516 & & 2433 & $100.0 \%$ & $0.89[0.74,1.07]$ & \\
\hline Total events & 239 & & 257 & & & & \\
\hline \multicolumn{7}{|c|}{$\begin{array}{l}\text { Heterogeneity: } \text { Chi }^{2}=1.04, \mathrm{df}=3(P=0.79) ;\left.\right|^{2}=0 \% \\
\text { Test for overall effect: } Z=1.24(P=0.22)\end{array}$} & $\begin{array}{ccccccc} & 1 & 1 & 1 & 1 & 1 \\
0.1 & 0.2 & 0.5 & 1 & 2 & 5 & 10 \\
\text { Favours FPISAL } & \text { Favours BUDIF }\end{array}$ \\
\hline
\end{tabular}

Exacerbations resulting in admission to hospital were not significantly different between FP/SAL and BUD/F (four studies, OR 1.29 ; $95 \%$ CI 0.68 to $2.47, \mathrm{~N}=4053$ Figure 5).

Figure 5. Forest plot of comparison: I Combination fluticasone/salmeterol versus budesonide/formoterol, outcome: I.2 Participants experiencing exacerbations requiring admission to hospital.

\begin{tabular}{|c|c|c|c|c|c|c|c|c|}
\hline Stucty or Subgroup & \multicolumn{2}{|c|}{ FPISAL } & \multicolumn{2}{|c|}{ BUDIF } & Weight & $\begin{array}{c}\text { Odds Ratio } \\
\text { M-H, Fixed, 95\% Cl }\end{array}$ & $\begin{array}{c}\text { Odds Ratio } \\
\text { M-H, Fixed, 95\% } \mathrm{Cl}\end{array}$ & \\
\hline Aalbers 2004 & 0 & 219 & 1 & 215 & $9.2 \%$ & $0.33[0.01,8.04]$ & & \\
\hline Busse 2008 & 2 & 404 & 1 & 422 & $5.9 \%$ & $2.09[0.19,23.19]$ & & \\
\hline COMPASS & 15 & 1123 & 13 & 1105 & $78.8 \%$ & $1.14[0.54,2.40]$ & & \\
\hline EXCEL & 4 & 694 & 1 & 697 & $6.0 \%$ & $4.03[0.45,36.19]$ & & \\
\hline Total (95\% Cl) & & 2440 & & 2439 & $100.0 \%$ & $1.29[0.68,2.47]$ & & \\
\hline Total events & 21 & & 16 & & & & & \\
\hline $\begin{array}{l}\text { Heterogeneity: } \mathrm{Chi}^{2} \text {, } \\
\text { Test for overall effect }\end{array}$ & $\begin{array}{l}2.01, \mathrm{df}= \\
\mathrm{Z}=0.79\end{array}$ & $\begin{array}{l}=3(P= \\
(P=0.4\end{array}$ & $\begin{array}{l}0.57) ; 1^{2}= \\
13)\end{array}$ & $=0 \%$ & & & $\begin{array}{cccc}0.001 & 0.1 & 1 & 10 \\
\text { Favours FPISAL } & \text { Favours }\end{array}$ & $\begin{array}{l}1000 \\
\text { UDiF }\end{array}$ \\
\hline
\end{tabular}

The risk of an asthma-related serious adverse event did not differ significantly between treatments (three studies, OR 1.47; 95\% CI 0.75 to $2.86, \mathrm{~N}=4879$ Figure 6). 
Figure 6. Forest plot of comparison: I Combination fluticasone/salmeterol versus budesonide/formoterol, outcome: I.3 Asthma-related serious adverse event.

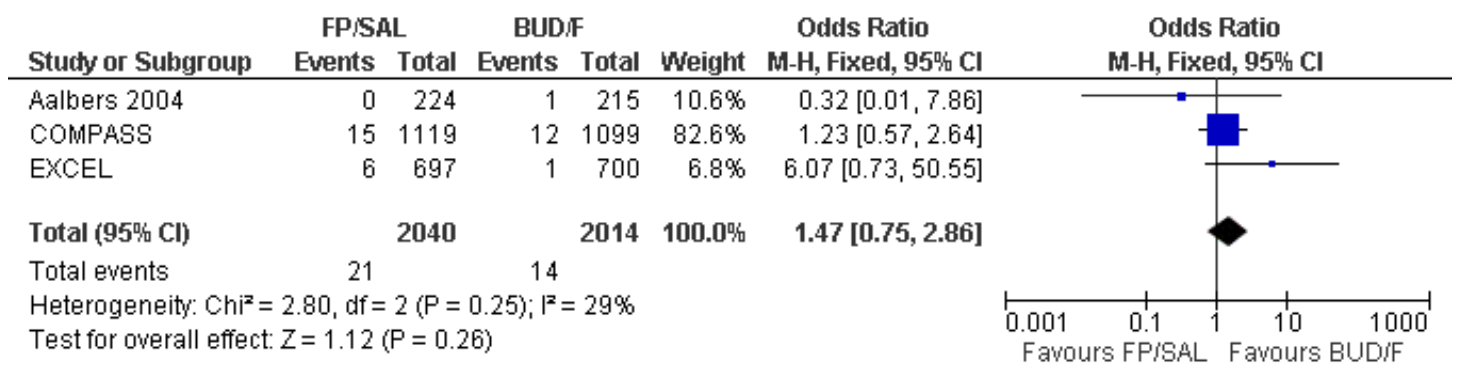

The Summary of Findings table conveys the results of these outcomes as absolute effects and our assessment of the strength of the evidence (Summary of findings for the main comparison).

\section{Secondary outcomes}

\section{Exacerbations requiring ED visit/hospital admission (composite)}

There was no statistically significant difference in the odds of ED visit/admission to hospital between the treatments (four studies, OR 1.3 ; $95 \%$ CI 0.94 to $1.8, \mathrm{~N}=4861$, Analysis 1.4).

\section{Diary card peak flow}

There was no significant difference between treatments in mean change in morning (five studies, $2.24 \mathrm{~L} / \mathrm{min}, 95 \% \mathrm{CI}-0.24$ to $4.73, \mathrm{~N}=5101$ ) or evening peak flow (four studies, $0.25 \mathrm{~L} / \mathrm{min}$; $95 \% \mathrm{CI}-0.80$ to $1.30, \mathrm{~N}=4299)$.

\section{FEV1}

There was no significant difference in the change from baseline between treatments (three studies, 0 Litres; $95 \%$ CI -0.02 to 0.02, $\mathrm{N}=4845)$.

\section{Symptoms \& rescue medication use}

There was no significant difference between treatments in the mean change in symptom scores (three studies, -0.02 ; 95\% CI 0.6 to $0.03, \mathrm{~N}=3464$ ). There was also no significant difference in change in rescue medication (three studies -0.06 puffs per day; $95 \%$ CI -0.13 to $0.02, \mathrm{~N}=3469$ ).

\section{Withdrawals and tolerability}

Study withdrawals were not significantly more frequent with either treatment in terms of overall discontinuations (Analysis 1.13), or when withdrawal due to adverse events or lack of efficacy were considered Analysis 1.14; Analysis 1.15. Headache, upper respiratory tract infection, dysphonia and throat irritation did not differ significantly between treatments (Analysis 1.17; Analysis 1.20; Analysis 1.19; Analysis 1.22).

A summary of findings table has been incorporated to this version of the review. This outlines our assessment of the overall quality of the evidence based on the risk of bias assessments, availability of data, imprecision of our analyses, and size and direction of the results (Summary of findings for the main comparison). In view of the absence of studies in children, the findings of the review are directly relevant to adults with asthma.

\section{DISCUSSION}

This review has collected data from five well-designed studies randomising over 5000 patients. No studies recruited children under the age of 12 years. The dose comparisons across the studies were similar, except for SAM 40048 where the dose of budesonide was half of that in the other studies. Based on UK recommendations, the BUD/F dose was the maximum licensed dosing for asthma in the UK, and the FP/SAL dose is the medium dose recommended in the UK for asthma (BNF 2007). We identified three co-primary outcomes, two pertaining to different severities of asthma exacerbation (those requiring oral steroid treatment, and those leading to hospitalisation), and one relating to asthma-related serious adverse events. None of the results were statistically significant. Our assessment of the quality of the evidence for these outcomes was moderate. Findings from these three endpoints will be considered first.

Requirement for a course of oral steroid treatment is a treatmentdriven rather than symptom-driven definition, but gives some in- 
dication as to whether maintenance therapy reduces inflammation sufficiently to prevent requirement for additional steroid. The ratio of such events was close to 1 in the three studies, and the BUD/ F event rate was similar between the trials (Aalbers 2004: 15\%; Busse 2008: 9\%; EXCEL: 11\%; COMPASS: 10\%). The lack of a statistically significant difference may reflect the effectiveness of combination therapy in reducing exacerbations when added to monotherapy ICS (Greenstone 2005).

The risk of hospitalisation did not differ significantly between therapies, although the confidence interval was wide and further evidence is necessary before a conclusion of no difference could be drawn definitively. The morbidity associated with hospital admission is considerable, and may indicate severe uncontrolled disease as well as predict future hospitalisation and mortality (Suissa 2001). Superiority of FP over BUD in dose ratio comparisons of 1 : 1 and 1:2 has been demonstrated for lung function endpoints, but not exacerbation rate data (Adams 2007). Our composite analysis of ED visit/hospitalisation did not show a significant difference between the treatments in contrast to a previous meta-analysis (Edwards 2007). The data for that analysis were in part based upon hospitalisation data from EXCEL and not additional ED visits from that study. Given that the data we obtained from GSK suggested parity between these event rates, we consider our data to represent a more complete assessment of the evidence available.

Based on evidence of harm, the use of LABAs as monotherapy is not recommended with serious adverse event data from previous studies implicating the bronchodilatory effects of LABAs as a possible mask for under-treated deterioration in underlying airway inflammation (Walters 2007; Cates 2008a; Cates 2008b). Serious adverse events did not occur with sufficient frequency in the studies to give precision to the results of our meta-analysis. The relative effects of either treatment in terms of serious harms remain to be fully elucidated. Based on evidence drawn from other comparisons involving adding LABA to ICS preparations, these therapies are well-tolerated (Greenstone 2005; Ni Chroinin 2005).

Neither lung function parameters, symptom scores nor rescue medication use identified statistically significant differences between treatments. Adverse event data indicated that the drugs were equally well-tolerated.

There are several limitations of the review. We limited our analyses to parallel studies on the assumption that optimum washout in steroid trials is uncertain, and that our primary outcome of exacerbations was best measured in long-term studies with a between- patient design. We have assumed that requirement for oral steroids and admission to hospital are independent, although it is reasonable to expect that poor asthma control associated with lack of adherence to maintenance inhaled steroids is likely to predict both (Williams 2004). Assessment of patient severity was confined to GINA defined control status, and this may not be sensitive enough to discern between severities of asthma. The major limitation of the studies themselves is the absence of data in children under the age of 12 years.

\section{A U THOR S' CONCLUSIONS Implications for practice}

The confidence intervals for our estimates in our primary outcomes include no statistically significant difference. However, the width of the confidence intervals for these endpoints also include possibly meaningful differences between the treatments in either direction and as such more evidence would help to improve their precision. Serious adverse events were too infrequent to generate findings which could be easily interpreted. Our analyses could not detect significant differences between these drugs in terms of lung function and symptoms. These observations pertain to adults and adolescents whose asthma is not adequately controlled with high doses of inhaled steroids.

\section{Implications for research}

The findings of our review would be strengthened by more data on exacerbations from further trials, in particular trials that include visits to emergency departments and hospitalisation. Evidence is required to establish the ratio of serious adverse events between these two drugs. Evidence for the effects of these drugs in children is also required.

\section{ACKNOWLEDGEMENTS}

We thank Susan Hansen for assistance in designing a search strategy and for electronic literature searching, and Veronica Stewart for assistance in retrieving the papers. We are grateful to René Aalbers, Jeff Fletcher and Steve Edwards from AZ in our efforts to obtain data for the Aalbers 2004 and COMPASS. We are grateful to Pim Kon and Richard Fellows from GSK for assisting us in obtaining ED visit data for EXCEL. 


\section{R E F E R E N C E S}

\section{References to studies included in this review}

\section{Aalbers 2004 \{published and unpublished data\}}

* Aalbers R, Backer V, Kava TT, Omenaas ER, Sandstrom

$\mathrm{T}$, Jorup $\mathrm{C}$, et al.Adjustable maintenance dosing with budesonide/formoterol compared with fixed-dose salmeterol/fluticasone in moderate to severe asthma. Current Medical Research \& Opinion 2004;20(2):225-40. Aalbers R, Backer V, Kava TT, Welte T, Omenaas ER, Bergqvist PBF, et al.Adjustable dosing with budesonide/ formoterol reduces the rate of asthma exacerbations compared with fixed dosing salmeterol/fluticasone. European Respiratory Society. 2003. [: p-2-20] Aalbers R, Harris A, Naya I. Adjustable dosing with budesonide/formoterol achieves sustained guideline 'wellcontrolled asthma' following step down in treatment. European Respiratory Journal 2005;26(Suppl 49):50s. Aalbers R, Welte T, Jorup C. Adjustable maintenance dosing (AMD) with budesonide/formoterol (B/F) meets guideline-defined management goals more effectively than fixed dosing (FD) with B/F or salmeterol/fluticasone (S/ FL). European Respiratory Journal 2004;24(Suppl 48):311s. Astrazenca (SD-039-0686). A randomized, doubledummy, double-blind/open, parallel-group, phase-III, multicentre, 7-month study to assess the efficacy and safety of Symbicort ${ }^{\circledR}$ Turbuhaler ${ }^{\circledR}$ (budesonide/formoterol; 160/ $4.5 \mathrm{mcg}$ delivered dose) given either as standard therapy (2 inhalations bid) or with an adjustable dosing regimen (1, 2 or 4 inhalations bid) versus Seretide ${ }^{\mathrm{TM}}$ Diskus ${ }^{\mathrm{TM}}$ (salmeterol/fluticasone; 50/250 mcg metered dose) given as standard therapy (1 inhalation bid) in adult and adolescent asthmatic patients. AstraZeneca Clinical Trials Register issue http://www.astrazenecaclinicaltrials.com/Article/ 512577.aspx [Accessed 19/10/2007].

Welte T, Aalbers R, Naya I. Budesonide/formoterol adjustable maintenance dosing (B/F AMD) reduces the burden of asthma more effectively than fixed-dosing (FD) with B/F or salmeterol/fluticasone (S/FL). European Respiratory Journal 2004;24(Suppl 48):508s.

Busse 2008 \{published and unpublished data\}

Ambrose H, Lawrance R, Goldman M. Beta-adrenergic receptor for Gly16Arg variation: Effect on response to Budesonide/Formoterol or Fluticasone/Salmeterol in asthma patients. Chest 2007:478s.

AstraZeneca (D5896C00005). A two-stage randomized, open-label, parallel group, phase III, multicenter, 7 month study to assess the efficacy and safety of Symbicort pMDI administered either as fixed or as an adjustable regimen versus a fixed regimen of Advair in subjects 12 years of age and older with asthma. AstraZeneca Clinical Trials Register (http://www.astrazenecaclinicaltrials.com) 2006 (accessed 13th March 2008).

Bleecker E, Postma DS, Lawrance RM, Meyers

DA, Ambrose HJ, Goldman M. Effect of ADRB2

polymorphisms on response to long-acting $\beta 2$-agonist therapy: a pharmacogenetic analysis of two randomised studies. Lancet 2008;370(9605):2118-25.

Bleecker ER, Lawrance R, Ambrose H, Goldman M. Beta2adrenergic receptor Gly16Arg variation: effect on response to budesonide/formoterol (BUD/FM) or budesonide (BUD; post-formoterol) in children and adolescents with asthma [Abstract]. American Thoracic Society International Conference, May 16-21. 2008.

Busse WW, Shah SR, Somerville L, Martin P, Goldman $\mathrm{M}$. Comparison of asthma exacerbations and lung function with adjustable-dose Budesonide/Formoterol pressurized metered-dose inhaler (BUD/FM pMDI), fixed-dose BUD/FM pMDI, and fixed-dose Fluticasone/ Salmeterol dry powder inhaler (FP/SM DPI). http:// www.abstracts2view.com/ats07 (accessed 13th March 2008) 2007:A191.

* Busse WW, Shah SR, Somerville L, Parasuraman B, Martin P, Goldman M. Comparison of adjustable- and fixed-dose budesonide/formoterol pressurized metered-dose inhaler and fixed-dose fluticasone propionate/salmeterol dry powder inhaler in asthma patients. Journal of Allergy and Clinical Immunology 2008; Vol. 121, issue 6:1407-14. O'Connor RD, Patrick DL, Parasuraman MB, Martin P, Goldman M. Patient satisfaction during treatment with adjustable dose budesonide/formoterol pressurized metered dose inhaler (BUD/FM pMDI) fixed dose BUD/FM pMDI and fixed dose fluticasone/salmeterol dry powder inhaler (FP/SM DPI) [Abstract]. American Thoracic Society International Conference, May 16-21, 2008, Toronto. 2008:A609.

Shah SR, Busse WW, Somerville L, Martin P, Goldman M. Asthma control with adjustable- and fixed-dose Budesonide/ Formoterol pressurized metered-dose inhaler (BUD/FM pMDI) and fixed-dose Fluticasone/Salmeterol dry powder inhaler (FP/SM DPI). http://www.abstracts2view.com/ ats07 (accessed 13th March 2008) 2007:A192.

Somerville L, Busse WW, Shah SR, Martin P, Goldman M. Safety of adjustable-dose Budesonide (BUD)/Formoterol (FM) pressurized metered-dose inhaler (pMDI), fixeddose BUD/FM pMDI, and fixed-dose Fluticasone (FP)/ Salmeterol (SM) dry powder inhaler (DPI) in asthma patients. http://www.abstracts2view.com/ats07 (accessed 13th March 2008) 2007:A191.

\section{COMPASS \{published and unpublished data\}}

AstraZeneca. SD-039-0735. Comparison of the efficacy and safety of one inhalation of Symbicort ${ }^{\circledR}$ Turbuhaler ${ }^{\circledR}$ $160 / 4.5 \mu \mathrm{g}$ bid plus as-needed with two inhalations of SeretideTM EvohalerTM 25/125 $\mu \mathrm{g}$ bid plus Terbutaline Turbuhaler® $0.4 \mathrm{mg}$ as-needed, and one inhalation of Symbicort ${ }^{\circledR}$ Turbuhaler ${ }^{\circledR} 320 / 9 \mu \mathrm{g}$ bid plus Terbutaline Turbuhaler ${ }^{\circledR} 0.4 \mathrm{mg}$ as-needed. A 6-month, randomised, double-blind, double-dummy, parallel-group, activecontrolled, multicentre, phase IIIB study in adult and adolescent asthmatic patients.. AstraZeneca Clinical Trials 
2009.

AstraZeneca. SYM/050/DEC2007. Data on File.

Bleecker ER, Postma DS, Lawrance R, Meyers DA, Ambrose H, Goldman M. Effect of polymorphisms in the beta2-adrenergic receptor gene (ADRB2) on response to long-acting beta2-agonist (LABA) therapy. Journal Allergy and Clinical Immunology 2007;119(2):523.

Buhl R, Kuna P. Does the choice of ICS/LABA regimen influence exacerbation rates in asthma patients with high as needed use? [Abstract]. European Respiratory Journal 2007; 30(Suppl 51):617s.

* Kuna P, Peters MJ, Manjra AI, Jorup C, Naya IP, Martinez-Jimenez NE, et al.Effect of budesonide/formoterol maintenance and reliever therapy on asthma exacerbations. International Journal of Clinical Practice 2007;61(5): 725-36.

Price D, Wiren A, Kuna P. Cost-effectiveness of budesonide/ formoterol for maintenance and reliever asthma therapy. Allergy 2007;62(10):1189-98.

EXCEL \{published and unpublished data\} Dahl OR, Chuchalin A, Lindberg A, Jones M, Aggarwal $\mathrm{K}$, Gor D. EXCEL regular maintenance therapy with salmeterol/fluticasone propionate combination (SFC) reduces exacerbations more effectively than the formoterol/ budesonide combination (FBC). European Respiratory Journal 2004;24(Suppl 48):309s.

* Dahl R, Chuchalin A, Gor D, Yoxall S, Sharma R. EXCEL: A randomised trial comparing salmeterol/fluticasone propionate and formoterol/budesonide combinations in adults with persistent asthma. Respiratory Medicine 2006; 100(7):1152-62.

Dahl R, Chuchalin A, Ringdal N, Gor D, Jones M. Salmeterol/fluticasone (SFC) reduces moderate/severe exacerbations more effectively than formoterol/budesonide 9FBC) with sustained maintenance therapy EXCEL. American Thoracic Society International Conference; May 20-25; San Diego, California. 2005:Poster: F68. GlaxoSmithKline (SAM40040). A twenty-four week, randomised, double-dummy, double-blind, parallel group study to compare the rate of asthma exacerbations between SERETIDE DISKUS 50/250ig 1 inhalation bd and formoterol/budesonide Breath-Actuated Dry Powder Inhaler (BADPI) 4.5/160ìg 2 inhalations bd in subjects with moderate to severe asthma. GlaxoSmithKline Clinical Trials Register issue http://ctr.gsk.co.uk/Summary/ fluticasone' salmeterol/IV·SAM40040.pdf [Accessed 19/10/ 2007].

\section{SAM40048 \{unpublished data only\}}

GlaxoSmithKline (SAM40048). Randomised, doubleblind, parallel group study on the efficacy and tolerability of the salmeterol $50 \mathrm{mcg} /$ fluticasone $250 \mathrm{mcg}$ combination Diskus compared to the formoterol $6 \mathrm{mcg} /$ budesonide $200 \mathrm{mcg}$ combination turbohaler administered twice daily in patients with moderate bronchial asthma. GlaxoSmithKline Clinical Trial Register 2005, issue http://ctr.gsk.co.uk/ Summary/fluticasone salmeterol/IV'SAM40048.pdf [Accessed 19/10/2007].

\section{References to studies excluded from this review}

\section{Adachi 2008 \{published data only\}}

Adachi M, Aizawa H, Ishihara K, Ohta K, Sano Y, Taniguchi $\mathrm{H}$, et al.Comparison of salmeterol/fluticasone propionate (FP) combination with FP+sustained release theophylline in moderate asthma patients. Respiratory Medicine 2008;102 (7):1055-64

\section{AHEAD \{published data only\}}

AstraZeneca. Efficacy and safety of Symbicort ${ }^{\circledR}$ Turbuhaler® 160/4.5 $\mu \mathrm{g}$ /inhalation, two inhalations twice daily plus as-needed compared with Seretide ${ }^{\mathrm{TM}}$ Diskus $^{\mathrm{TM}}$ $50 / 500 \mu \mathrm{g} /$ inhalation, one inhalation twice daily plus terbutaline Turbuhaler $0.4 \mathrm{mg} /$ inhalation as-needed - a 6 month, randomised, double-blind, parallel-group, active controlled, multinational phase IIIB study in adult and adolescent patients with persistent asthma (AHEAD). www.clinicaltrials.gov 2005.

AstraZeneca (D5890C00002). Efficacy and safety of Symbicort ${ }^{\circledR}$ Turbuhaler ${ }^{\circledR} 160 / 4.5 \mathrm{mcg} /$ inhalation, two inhalations twice daily plus as-needed compared with Seretide Diskus 50/500 mcg/inhalation, one inhalation twice daily plus terbutaline Turbuhaler $0.4 \mathrm{mg} /$ inhalation as-needed - a 6-month, randomised, double-blind, parallelgroup, active controlled, multinational phase IIIB study in adult and adolescent patients with persistent asthma.. http: //www.astrazenecaclinicaltrials.com (accessed 12th May 2008) 2007.

Bousquet J, Boulet L-P. Budesonide/formoterol as maintenance and reliever therapy in uncontrolled asthma compared with high dose salmeterol/fluticasone: the AHEAD double blind study [Abstract]. European Respiratory Journal 2007;30(Suppl 51):358s.

* Bousquet J, Boulet L-P, Peters MJ, Magnussen H, Quiralte J, Martinez-Aguilar NE, Carlsheimer A. Budesonide/ formoterol for maintenance and relief in uncontrolled asthma versus high-dose salmeterol/fluticasone. Respiratory Medicine 2007;101(12):2437-46.

Bousquet J, Miravitlles M, Wiren A. Budesonide / formoterol provides better efficacy at a lower or similar cost as compared to high dose salmeterol fluticasone treatment [Abstract]. European Respiratory Journal 2007;30(Suppl 51):193s.

\section{ALLIANCE \{published data only\}}

* Molimard M, Le Gros V, Bourdeix I. Efficacy of formoterol and beclomethasone dry powder capsules in asthmatic patients sub-optimally controlled with fixed combination formoterol-budesonide ALLIANCE study. European Respiratory Journal 2004;24(Suppl 48):261s.

\section{Ambrose 2007 \{published data only\}}

Ambrose H, Lawrance R, Goldman M. Beta-adrenergic receptor gly16arg variation: effect on response to budesonide/formoterol or budesonide (post-formoterol) in asthma patient. Chest 2007;132(4):436a. 


\section{Bleecker 2007 \{published data only\}}

Bleecker E, Yancey S, Ortega H, Anderson W. Arginine 16 genotype does not modulate clinical response to salmeterol in subjects with asthma. Chest 2007;132(4):436.

Brambilla 2003 \{published data only\} Brambilla C, Le Gros V, Bourdeix I, Efficacy of Foradil in Asthma (EFORA) French Study Group. Formoterol 12 microg BID administered via single-dose dry powder inhaler in adults with asthma suboptimally controlled with salmeterol or on-demand salbutamol: a multicenter, randomized, open-label, parallel-group study. Clinical Therapeutics 2003;25(7):2022-36.

\section{CONCEPT \{published data only\}}

Fitzgerald JM, Boulet LP, Follows R. Improved control of symptoms, exacerbations and quality of life with stable dose treatment with salmeterol/fluticasone (SFC) compared with adjustable maintenance dosing with formoterol/budesonide. XIX World Allergy Organization Congress, June 26-July 1, Munich, Germany. 2005:Abstract 289.

* FitzGerald JM, Boulet LP, Follows RMA. The CONCEPT trial: A 1-year, multicenter, randomized, double-blind, double-dummy comparison of a stable dosing regimen of salmeterol/fluticasone propionate with an adjustable maintenance dosing regimen of formoterol/ budesonide in adults with persistent asthma. Clinical Therapeutics 2005; 27(4):393-406.

Fitzgerald M, Boulet LP, Pieters WR. Improved control of symptoms and exacerbations with stable dose treatment with salmeterol/fluticasone propionate (SFC) compared with adjustable maintenance dosing with formoterol/ budesonide (FBC). European Respiratory Journal 2005; Vol. 26, issue Suppl 49:Abstract No. 2765.

GlaxoSmithKline (SAM40056). A randomised, doubleblind, double-dummy, 52 week, parallel group study of a standard dosing regimen with salmeterol/fluticasone combination $50 / 250 \mathrm{mcg}$ bid (via the DISKUS/ ACCUHALER inhaler) versus a symptom-driven, variable dosing regimen with formoterol/budesonide combination 6/200mcg (via a breath-actuated dry powder reservoir inhaler) in adult asthmatics. GlaxoSmithKline Clinical Trial Register 2005, issue http:/ctr.gsk.co.uk/Summary/ fluticasone salmeterol/IV· SAM40056.pdf [Accessed 19/10/ 2007].

Price DB, Williams AE, Yoxall S. Salmeterol/fluticasone stable-dose treatment compared with formoterol/ budesonide adjustable maintenance dosing: impact on health-related quality of life. Respiratory Research 2007;8:46.

\section{Creemers 2002 \{published data only\}}

Creemers JP, Bantje T, Eliraz A, Ekstrom T, Buhl R. Budesonide/formoterol in a single inhaler once or twice daily provides better control than inhaled fluticasone or budesonide alone in patients with moderate persistent asthma. European Respiratory Journal 2002;20(Suppl 38): 387s.

EDICT \{published data only\}

Alonso JF, Badiola C, Kielhorn A. Economic evaluation of salmeterol/fluticasone combination versus budesonide plus formoterol in Spain. European Respiratory Journal 2001;18

(Suppl 33):49s

Chuchalin AG, Chovan L, Ringdal N, Whitehead PJ.

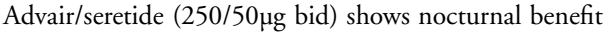
over budesonide $800 \mu \mathrm{g}+$ formoterol $12 \mu \mathrm{g}$ bid in moderatesevere asthma. American Journal of Respiratory and Critical Care Medicine. 2001; Vol. 163, issue Suppl 5:A866. Jenkins C, Wilson J, Rutherford C, Perry AS, Whitehead PJ. Asthma management costs are lower with combination fluticasone/salmeterol $(25 / 50 \mathrm{mcg} B D)$ in a single inhaler than with budesonide ( $800 \mathrm{mcg} \mathrm{BD})$ plus eformoterol (12 mcg BD) via separate inhalers. Respirology 2002;7(Suppl): A20

Martin AA, Whitehead PJ, McCarthy TP. Asthma costs with salmeterol/fluticasone combination $50 / 250 \mathrm{mcg}$ bd compared to budesonide $800 \mathrm{mcg}$ bd plus formoterol $12 \mathrm{mcg}$ bd [Abstract]. American Thoracic Society 99th International Conference. 2003:D034 Poster C43. Price MJ, Karia N, Whitehead P. Comparison of asthma treatment costs of salmeterol/fluticasone combination product $50 / 250 \mathrm{mcg}$ bid with budesonide $800 \mathrm{mcg}$ plus formoterol 12mcg bid. European Respiratory Journal 2000; 16(Suppl 31):353s

Ringdal N, Chovan L, Chuchalin AG, Whitehead PJ. Advair/seretide $(250 \mu \mathrm{g} / 50 \mu \mathrm{g}$ bid) shows exacerbation benefit over budesonide $800 \mu \mathrm{g}+$ formoterol $12 \mu \mathrm{g}$ in moderate-severe asthma. American Journal of Respiratory and Critical Care Medicine 2001;163(Suppl 5):A866.

* Ringdal N, Chuchalin A, Chovan L, Tudoric N, Maggi E, Whitehead PJ, et al.Evaluation of different inhaled combination therapies (EDICT): A randomised, doubleblind comparison of Seretide (50/250 mug bd Diskus vs. formoterol (12 mug bd) and budesonide (800 mug bd) given concurrently (both via Turbuhaler) in patients with moderate-to-severe asthma. Respiratory Medicine 2002;96 (11):851-61.

SAS40002 (SERL05). A randomised, double-blind, double-dummy, parallel-group comparison of Seretide (Diskus/Accuhaler) 250/50 $\mu \mathrm{g}$ bid with Budesonide $800 \mu \mathrm{g}$ bid plus Formoterol $12.0 \mu \mathrm{g}$ bid (both via breath-actuated dry powder inhaler) in adolescent and adult moderatesevere asthmatics. GlaxoSmithKline Clinical Trials Register issue http://ctr.gsk.co.uk/Summary/fluticasone salmeterol/ III'SAS40002.pdf [Accessed 19/10/2007].

\section{Hampel 2007 \{published data only\}}

Hampel FC, Martin P, Mezzanotte WS. Early bronchodilatory effects of budesonide/formoterol pMDI compared with fluticasone/salmeterol DPI and albuterol pMDI: 2 randomized controlled trials in adults with persistent asthma previously treated with inhaled corticosteroids. Journal of Asthma 2008;45(4):265-72. Hampel Jr FC, Martin P, Mazzanotte WS. Early bronchodilatory effects of budesonide formoterol pressurized metered dose inhaler ( $\mathrm{pMDI}$ ) compared with fluticasone propionate salmeterol dry powder inhaler (DPI) and albuterol pMDI in adults with asthma [Abstract]. Journal of Allergy and Clinical Immunology 2008;121(2 
Suppl 1):S220

Jenkins 2000 \{published and unpublished data\}

Becker I, Kielborn A, Price MJ, Volmer T, Lloyd AC. Costeffectiveness of salmeterol/fluticasone combination product and budesonide in asthma patients in Germany. European Respiratory Society; 1999 Oct 9-13; Madrid, Spain. 1999: 854.

* Jenkins C, Woolcock AJ, Saarelainen P, Lundbaack B James MH. Salmeterol /fluticasone propionate combination therapy $50 / 250 \mathrm{mcgs}$ twice daily is more effective than budesonide 800 twice daily in treating moderate to severe asthma.. Repiratory Medicine 2000;94:715-23.

Jenkins C, Woolcock A James M. Superior overall control of moderate to severe asthma with salmeterol/fluticasone propionate (FP) combination (50/250 mcg bd) compared with three-fold-higher dose of budesonide $(800 \mathrm{mcg}$ bd). European Respiratory Journal. 2000; Vol. 16, issue Suppl 31:456s.

Lundback B, Jenkins C, Price MJ, Thwaites RM. Cost-effectiveness of salmeterol/fluticasone propionate combination product 50/250 microg twice daily and budesonide 800 microg twice daily in the treatment of adults and adolescents with asthma. Respiratory Medicine 2000;94(7):724-32.

Lundback B, Ronmark E, Jonsson AC, et al.Treatment effectiveness and exacerbations during one year with Seretide compared to fluticasone propionate and salmeterol in mild to moderate asthma. European Respiratory Journal 2001; Vol. 18, issue Suppl 33:176s.

SAS40006. A randomised, double-blind, double-dummy, parallel group comparison of Seretide Diskus/Accuhaler

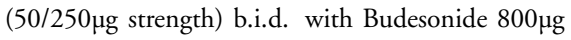
b.i.d. in adolescents and adults with reversible airways obstruction. http://www.clinicalstudyresults.org issue http://ctr.gsk.co.uk/Summary/fluticasone' salmeterol/ IV'SAS40006.pdf [Accessed 19/10/2007].

\section{Kaik 2002 \{published data only\}}

Kaik G, Kottakis I, Anagnostopoulou O, Sichletidis L, Bachlitzanakis N, D'Amato M, et al.Sequential flexible therapy with formoterol (Foradil $囚$ ) plus budesonide (Miflonide ${ }^{\circledR}$ ) versus a fixed combination of salmeterol and fluticasone (Seretide $\left.{ }^{\circledR}\right)$ in asthma self-management. European Respiratory Society Annual Congress. 2002: abstract nr: P2407.

Lee 2003 \{published data only\}

* Lee DK, Jackson CM, Currie GP, Cockburn WJ, Lipworth B J. Comparison of combination inhalers versus inhaled corticosteroids alone in moderate persistent asthma. British Journal of Clinical Pharmacology 2003;56(5):494-500. Lee DKC, Currie GP, Cockburn WJ, Lipworth BJ. Budesonide/formoterol and fluticasone/salmeterol combination inhalers delay immediate albuterol recovery following acute bronchoconstriction. Journal of Allergy and Clinical Immunology 2003;111(Suppl 2):202s.

Lee DKC, Currie GP, Cockburn WJ, Lipworth BJ. Comparison of budesonide/formoterol versus fluticasone/ salmeterol combination inhalers in moderate persistent asthma. American Thoracic Society 99th International Conference. 2003:D094 Poster 613.

Lotväll 2002 \{published data only\}

Lötvall J, van der Woude HJ, Palmqvist M, Arvidsson P, Beckman O, Boorsma $\mathrm{M}$, et al.More rapid onset of action of budesonide/formoterol (Symbicort ${ }^{\circledR}$ ) than salmeterol/ fluticasone (seretide ${ }^{\mathrm{TM}}$ ). American Journal of Respiratory and Critical Care Medicine 2002;165(Suppl 8):A567.

\section{Palmqvist 2001 \{published data only\}}

AstraZeneca (SD-039-0617). Onset of Action of Symbicort Turbuhaler ${ }^{\circledR}$ compared with Seretide Diskus ${ }^{\mathrm{TM}}$ in asthmatic patients. http://www.astrazenecaclinicaltrials.com/article/ 512581.aspx [Accessed 19/10/2007].

* Palmqvist M, Arvidsson P, Beckman O, Peterson S, Lotvall $\mathrm{J}$. Onset of bronchodilation of budesonide/formoterol versus salmeterol/fluticasone in single inhalers. Pulmonary Pharmacology \& Therapeutics 2001;14(1):29-34.

\section{SAM40042 \{unpublished data only\}}

GlaxoSmithKline (SAM40042). A double-blind, doubledummy, randomised, cross-over study to compare the bronchodilator effect of SERETID ACCUHALER 50/ $100 \mathrm{mcg}$ and formoterol/budesonide combination breathactuated dry powder inhaler $6 / 200 \mathrm{mcg}$ in subjects with asthma following a single dose and after 4 weeks of regular treatment. GlaxoSmithKline Clinical Trial Register issue http://ctr.gsk.co.uk/Summary/fluticasone' salmeterol/ IV'SAM40042.pdf [Accessed 19/10/2007].

\section{SAM40047 \{unpublished data only\}}

GlaxoSmithKline (SAM40047). Duration of action of single inhalations of the salmeterol/fluticasone combination product $(50 / 250 \mu \mathrm{g})$ in comparison with the formoterol/ budesonide combination product $(4.5 / 160 \mu \mathrm{g})$ in patients with moderate asthma - a randomised, double-blind, double-dummy, crossover study. GlaxoSmithKline Clinical Trial Register issue http://ctr.gsk.co.uk/Summary/ fluticasone' salmeterol/IV·SAM40047.pdf [Accessed 19/10/ 2007].

\section{SAM40062 \{published data only\}}

GlaxoSmithKline (SAM40062). A single-centre, singledose, double-blind, double-dummy, placebo-controlled, randomised, three-way crossover study to compare the duration of action of SERETIDE DISKUS 50/100mcg versus formoterol/budesonide combination $4.5 / 160 \mathrm{mcg}$ breath-actuated dry powder inhaler (BADPI) in subjects with asthma. GlaxoSmithKline Clinical Trial Register 2005, issue http://ctr.gsk.co.uk/Summary/fluticasone salmeterol/ IV·SAM40062.pdf [Accessed 19/10/2007].

Vogelmeier 2005 \{published data only\}

D'Urzo A, Vogeimeier C, Jaspal M, Merino JM, Boulet S. Symbicort (budesonide/formoterol) for both maintenance and relief reduces the exacerbation burden compared with titration of seretide (salmeterol/fluticasone) in patients with asthma, a real life study. American Thoracic 
Society International Conference; May 20-25; San Diego, California. 2005:Poster G24.

Johansson G, Andreasson EB, Larsson PE, Vogelmeier CF. Cost effectiveness of budesonide/formoterol for maintenance and reliever therapy versus salmeterol/ fluticasone plus salbutamol in the treatment of asthma. Pharmacoeconomics 2006;24(7):695-708.

Miller E, Sears MR, McIvor A, Liovas A. Canadian economic evaluation of budesonide-formoterol as maintenance and reliever treatment in patients with moderate to severe asthma. Canadian Respiratory Journal 2007;14(5):269-75. Vogelmeier C, D’Urzo A. Maintenance plus as-needed budesonide/formoterol vs salmeterol/fluticasone in a reallife setting. European Respiratory Journal 2006; Vol. 26, issue Suppl 49:Ab no: 2770.

* Vogelmeier C, D’Urzo A, Pauwels R, Merino JM, Jaspal $\mathrm{M}$, Boutet $\mathrm{S}$, et al.Budesonide/formoterol maintenance and reliever therapy: An effective asthma treatment option?. European Respiratory Journal 2005;26(5):819-28.

\section{Additional references}

\section{Adams 2007}

Adams N, Bestall JM, Lasserson TJ, Jones PW. Fluticasone versus beclomethasone or budesonide for chronic asthma in adults and children. Cochrane Database of Systematic Reviews 2007, Issue 4. [Art. No.: CD002310. DOI: 10.1002/ 14651858.CD002310.pub4]

\section{Adams 2008}

Adams NP, Bestall JC, Lasserson TJ, Jones PW, Cates CJ. Fluticasone versus placebo for chronic asthma in adults and children. Cochrane Database of Systematic Reviews 2008, Issue 4. [Art. No.: CD003135. DOI: 10.1002/ 14651858.CD003135.pub4]

\section{BNF 2007}

British National Formulary. www.bnf.org 2007, issue 53.

\section{Cates 2008a}

Cates CJ, Cates MJ. Regular treatment with salmeterol for chronic asthma: serious adverse events. Cochrane Database of Systematic Reviews 2008, Issue 3. [DOI: 10.1002/ 14651858.CD006363.pub2]

\section{Cates 2008b}

Cates CJ, Cates MJ, Lasserson TJ. Regular treatment with formoterol for chronic asthma: serious adverse events.. Cochrane Database of Systematic Reviews 2008, Issue 4. [DOI: 10.1002/14651858.CD006923.pub2.]

\section{Cazzola 2002}

Cazzola M, Grella E, Matera MG, Mazzarella G, Marsico SA. Onset of action following formoterol Turbuhaler and salbutamol pMDI in reversible chronic airway obstruction. Pulmponary Pharmacology and Therapeutics 2002;15(2): 97-102.

\section{Edwards 2007}

Edwards SJ, Gruffydd-Jones K, Ryan DP. Systematic review and meta-analysis of budesonide/formoterol in a single inhaler. Current Medical Research and Opinion 2007;23(8): 1809-20.

\section{Gibson 2005}

Gibson PG, Powell H, Ducharme F. Long-acting beta2agonists as an inhaled corticosteroid-sparing agent for chronic asthma in adults and children. Cochrane Database of Systematic Reviews 2005, Issue 4. [Art. No.: CD005076. DOI: 10.1002/14651858.CD005076.pub2]

\section{GINA}

From the Global Strategy for Asthma Management and Prevention, Global Initiative for Asthma (GINA). http:// www.ginasthma.org 2006.

\section{Greenstone 2005}

Greenstone IR, Ni Chroinin MN, Masse V, Danish A, Magdalinos $\mathrm{H}$, Zhang X, et al.Combination of inhaled long-acting beta2-agonists and inhaled steroids versus higher dose of inhaled steroids in children and adults with persistent asthma. Cochrane Database of Systematic Reviews 2005, Issue 4. [Art. No.: CD005533. DOI: 10.1002/ 14651858.CD005533]

\section{Handbook 2005}

Higgins JPT, Green S, editors. Assessment of study quality. Cochrane Handbook for Systematic Reviews of Interventions 4.2.5 [updated May 2005] http://www.cochrane.org/ resources/handbook/hbook.htm (accessed 25th January 2007). Chichester: John Wiley \& Sons Ltd, 2005.

\section{Higgins 2003}

Higgins JPT, Thompson SG, Deeks JJ, Altman DG. Measuring inconsistency in meta-analyses. British Medical Journal 2003;327:557-60.

\section{Ni Chroinin 2005}

Ni Chroinin M, Greenstone IR, Danish A, Magdolinos H, Masse V, Zhang X, et al.Long-acting beta2-agonists versus placebo in addition to inhaled corticosteroids in children and adults with chronic asthma. Cochrane Database of Systematic Reviews 2005, Issue 4. [Art. No.: CD005535. DOI: 10.1002/14651858.CD005535]

\section{Palmqvist 1997}

Palmqvist M, Persson G, Lazer L, Rosenborg J, Larsson P, Lotvall J. Inhaled dry-powder formoterol and salmeterol in asthmatic patients: onset of action, duration of effect and potency. European Respiratory Journal 1997;10(11):2484-9.

\section{Suissa 2001}

Suissa S, Ernst P. Inhaled corticosteroids: impact on asthma morbidity and mortality. Journal of Allergy and Clinical Immunology 2001;107(6):937-44.

van Noord 1996

van Noord J, Smeets JJ, Raaijmakers JA, Bommer AM, Maesen FP. Salmeterol versus formoterol in patients with moderately severe asthma: onset and duration of action. European Respiratory Journal 1996;9:1684-8.

\section{Walters 2007}

Walters EH, Gibson PG, Lasserson TJ, Walters JA. Longacting beta2-agonists for chronic asthma in adults and children where background therapy contains varied or no inhaled corticosteroid. Cochrane Database of Systematic 
Reviews 2007, Issue 1. [Art. No.: CD001385. DOI:

10.1002/14651858.CD001385.pub2]

Williams 2004

Williams LK, Pladevall M, Xi H, Peterson EL, Joseph C,

Lafata JE, et al.Relationship between adherence to inhaled corticosteroids and poor outcomes among adults with

asthma. Journal of Allergy and Clinical Immunology 2004;

114(6):1288-93.

www.nntonline.net

Cates C. Visual Rx. www.nntonline.net 2001.

* Indicates the major publication for the study 
CHARACTERISTICS OF STUDIES

Characteristics of included studies [ordered by study ID]

Aalbers 2004

Methods

Randomised, parallel group trial. Open label design with adjustable dosing criteria 93 centres in Denmark, Finland, Germany, Norway, Sweden, Netherlands

Description of withdrawals:

Stated.

\begin{tabular}{|c|c|}
\hline Participants & $\begin{array}{l}\text { N SCREENED: Not reported (1044 enrolled in run-in period) } \\
\text { N RANDOMISED: } 658 \text { : FPS fixed dose: 224; BDF fixed dose: } 215 \text {; BDF adjustable } \\
\text { maintenance dose: } 219 \text { (not included in this review) } \\
\text { N COMPLETED: } 383 \\
\text { M= } 205 \\
\text { F= } 234 \\
\text { MEAN AGE: } 46 \\
\text { BASELINE CHARACTERISTICS: } \\
\text { FEV1 \% predicted: } 84 \text {; PEF L/min: } 468 \text {; } \% \text { combination LABA/ICS treatment at entry: } \\
\text { 45; asthma duration: } 12 \text {; Average ICS dose (BDP equivalent): } 735 \\
\text { GINA status: mild persistent } \\
\text { INCLUSION CRITERIA: } \\
>12 \text { years; minimum } 6 \text { months asthma duration (ATS definition); FEV1 predicted }>50 \% \text {; } \\
\text { ICS use > } 3 \text { months; stable dose +/- LABA; } \\
\text { Post-run-in entry criteria: symptom score }>1 \text { on at least } 4 \text { of last } 7 \text { days of run-in period; } \\
\text { mean PEF of } 50-85 \% \text { predicted; use of PEF meter to record DC data } \\
\text { EXCLUSION CRITERIA: } \\
\text { Respiratory infection }<4 \text { weeks prior to study entry; smoking history }>10 \text { pack years; use } \\
\text { of systemic steroids within } 4 \text { weeks of study entry; significant co-morbidities }\end{array}$ \\
\hline Interventions & $\begin{array}{l}\text { 1. Combination fluticasone and salmeterol } 250 / 50 \mathrm{mcg} \text { bid (double-blind phase); } 250 / \\
50 \text { bid fixed (open label phase). BDP equivalent } 1000 \mathrm{mcg} \\
\text { 2. Combination budesonide and formoterol } 400 / 12 \mathrm{mcg} \text { bid (double-blind phase); } 400 / \\
12 \text { bid fixed (open label phase). BDP equivalent } 800 \mathrm{mcg} \\
\text { 3. Combination budesonide and formoterol } 320 / 9 \mathrm{mcg} \text { bid (double-blind phase); } 320 / 9 \\
\text { bid or } 160 / 4.5 \text { bid plus temporary increase if needed (open label period). BDP equivalent } \\
800 \mathrm{mcg} \\
\text { DELIVERY DEVICE: } \\
\text { BUD/F: Turbuhaler; FP/SAL: Diskus } \\
\text { TREATMENT PERIOD: } \\
\text { Double-blind fixed dose period: } 4 \text { weeks; open label period: } 24 \text { weeks } \\
\text { RUN-IN: } 10-14 \text { days on ICS only } \\
\text { RESCUE: Terbutaline or salbutamol as preferred }\end{array}$ \\
\hline Outcomes & $\begin{array}{l}\text { Primary outcome: Well controlled asthma week } \\
\text { Secondary outcomes: } \\
\text { Am PEF; pm PEF; FEV1; rescue medication use; symptoms; exacerbations (requiring } \\
\text { OCS treatment on }>3 \text { days; hospitalisation or ER treatment) }\end{array}$ \\
\hline
\end{tabular}


Aalbers 2004 (Continued)

\begin{tabular}{|c|c|c|}
\hline Notes & \multicolumn{2}{|c|}{$\begin{array}{l}\text { DOSE ADJUSTMENT CRITERIA: Step down to one inhalation bid if symptoms } \\
\text { controlled for last week of double-blind period; increase to up to four inhalations bid } \\
\text { (for 7-14 days) of symptomatic over last week of double-blind period } \\
\text { Study sponsors: AstraZeneca }\end{array}$} \\
\hline \multicolumn{3}{|l|}{ Risk of bias } \\
\hline Item & Authors' judgement & Description \\
\hline Adequate sequence generation? & Yes & $\begin{array}{l}\text { 'The randomisation schedule was gener- } \\
\text { ated using a computer programme by a } \\
\text { statistician (...) Patients were consecutively } \\
\text { allocated to the lowest available patient } \\
\text { number and were randomised strictly se- } \\
\text { quentially in blocks.' }\end{array}$ \\
\hline Allocation concealment? & Yes & $\begin{array}{l}\text { Third party not involved with primary } \\
\text { study. }\end{array}$ \\
\hline $\begin{array}{l}\text { Blinding? } \\
\text { OCS treated exacerbations \& hospitalisa- } \\
\text { tion }\end{array}$ & Yes & $\begin{array}{l}\text { Open label study design not a threat to pri- } \\
\text { mary outcomes in this review }\end{array}$ \\
\hline $\begin{array}{l}\text { Incomplete outcome data addressed? } \\
\text { OCS treated exacerbations }\end{array}$ & Unclear & $\begin{array}{l}\text { ITT analysis described; no explicit details } \\
\text { on how withdrawals were handled }\end{array}$ \\
\hline $\begin{array}{l}\text { Incomplete outcome data addressed? } \\
\text { Hospital admission }\end{array}$ & Unclear & $\begin{array}{l}\text { ITT analysis described; no explicit details } \\
\text { on how withdrawals were handled }\end{array}$ \\
\hline Free of selective reporting? & Unclear & Unable to ascertain this reliably \\
\hline Free of other bias? & Yes & \\
\hline
\end{tabular}

\section{Busse 2008}

\begin{tabular}{ll} 
Methods & $\begin{array}{l}\text { Randomised, parallel group open label design with adjustable dosing criteria (from } \\
\text { month } 2 \text { onwards). Participants randomised 2:1 to receive fixed dose BUD/F or FP/ } \\
\text { SAL. Subsequently BUD/F treated participants were re-randomised to continue with } \\
\text { fixed dose regimen or adjustable maintenance dosing } \\
145 \text { centres in USA } \\
\text { Description of withdrawals: stated }\end{array}$ \\
\hline Participants & N SCREENED: 2080 \\
N RANDOMISED: 1225 \\
N COMPLETED: 1052 \\
M= 490 \\
F=735 \\
MEAN AGE: 39
\end{tabular}




\begin{tabular}{|c|c|c|}
\hline & \multicolumn{2}{|c|}{$\begin{array}{l}\text { BASELINE CHARACTERISTICS: FEV1 } 79 \% \text { predicted } \\
\text { INCLUSION CRITERIA: > } 12 \text { years; ATS defined asthma for } 6 \text { months; stable condi- } \\
\text { tion; pre-bronchodilator FEV1 }>/=50 \% \text { predicted; maintained on a daily medium-dose } \\
\text { ICS or ICS/LABA combination for } 12 \text { weeks or longer before screening } \\
\text { EXCLUSION CRITERIA: Systemic corticosteroid use within } 30 \text { days; } 20 \text { pack-year } \\
\text { or longer smoking history; significant disease, respiratory tract infection, or illness that } \\
\text { might interfere with lung function/study participation }\end{array}$} \\
\hline Interventions & \multicolumn{2}{|c|}{$\begin{array}{l}\text { 1. Combination fluticasone and salmeterol } 250 / 50 \mathrm{mcg} \text { BID } \\
\text { 2. Combination budesonide and formoterol 400/12mcg BID } \\
\text { DELIVERY DEVICE: BUD/F: MDI; FP/SAL: DPI } \\
\text { TREATMENT PERIOD: } 7 \text { months } \\
\text { RUN-IN: } 10-14 \text { days } \\
\text { RESCUE: prn SABA }\end{array}$} \\
\hline Outcomes & \multicolumn{2}{|c|}{$\begin{array}{l}\text { Primary outcome: Time to first exacerbation } \\
\text { Secondary outcomes: Exacerbations requiring OCS; hospitalisation; ED visits; FEV1; } \\
\text { am PEF; symptoms; rescue medication use; adverse events; withdrawals }\end{array}$} \\
\hline Notes & \multicolumn{2}{|c|}{ Study sponsors: AstraZeneca } \\
\hline \multicolumn{3}{|l|}{ Risk of bias } \\
\hline Item & Authors' judgement & Description \\
\hline Adequate sequence generation? & Yes & $\begin{array}{l}\text { Computer generated randomisation se- } \\
\text { quence. }\end{array}$ \\
\hline Allocation concealment? & Yes & $\begin{array}{l}\text { Third party not involved with primary } \\
\text { study }\end{array}$ \\
\hline $\begin{array}{l}\text { Blinding? } \\
\text { OCS treated exacerbations \& hospitalisa- } \\
\text { tion }\end{array}$ & Yes & $\begin{array}{l}\text { Open label study design not a threat to pri- } \\
\text { mary outcomes in this review }\end{array}$ \\
\hline $\begin{array}{l}\text { Incomplete outcome data addressed? } \\
\text { OCS treated exacerbations }\end{array}$ & Unclear & $\begin{array}{l}\text { Intention to treat population described as: } \\
\text { 'Efficacy analyses included randomized pa- } \\
\text { tients who received } 1 \text { or more doses of ran- } \\
\text { domized study medication and contributed } \\
\text { data sufficient to calculate } 1 \text { or more pri- } \\
\text { mary or secondary efficacy end points.' }\end{array}$ \\
\hline $\begin{array}{l}\text { Incomplete outcome data addressed? } \\
\text { Hospital admission }\end{array}$ & Unclear & $\begin{array}{l}\text { Intention to treat population described as: } \\
\text { 'Efficacy analyses included randomized pa- } \\
\text { tients who received } 1 \text { or more doses of ran- } \\
\text { domized study medication and contributed } \\
\text { data sufficient to calculate } 1 \text { or more pri- } \\
\text { mary or secondary efficacy end points.' }\end{array}$ \\
\hline
\end{tabular}


Busse 2008 (Continued)

\begin{tabular}{l|l|l}
\hline Free of selective reporting? & Unclear & Unable to ascertain this reliably. \\
\hline Free of other bias? & Yes & \\
\hline
\end{tabular}

\section{COMPASS}

Methods

Randomised, parallel group trial. Double-blind, treble-dummy design

235 centres in 16 countries.

Description of withdrawals: Stated

\begin{tabular}{|c|c|}
\hline Participants & $\begin{array}{l}\text { N SCREENED: Not reported ( } 4399 \text { enrolled) } \\
\text { N RANDOMISED: } 2228 \text { (two treatment groups: FPS: 1123; BDF: 1105; one treatment } \\
\text { group not considered by this review: BDF (plus BDF as needed): 1107). } \\
\text { N COMPLETED: } 2120 \\
\text { M= } 932 \\
\text { F= } 1296 \\
\text { MEAN AGE: } 38 \text { (N } 12-17 \text { years: } 424 \text {; >18 years: } 1696 \text { ) } \\
\text { BASELINE CHARACTERISTICS: } \\
\text { FEV1 predicted: } 73 \% \text {; mean ICS consumption at baseline: } 747 \mathrm{mcg} / \mathrm{d} \text {; } \\
\text { INCLUSION CRITERIA: } \\
>12 \text { years; ATS defined asthma for }>6 \text { months; use of ICS }>3 \text { months }(500 \mathrm{mcg} / \mathrm{d} \text { FP } \\
\text { or equivalent); }>50 \% \text { predicted FEV1; }>1 \text { exacerbation in previous } 12 \text { months; use of } \\
\text { reliever medication >5 days of previous } 7 \text { during run-in. } \\
\text { EXCLUSION CRITERIA: } \\
\text { >puffs/d rescue medication on any day of run-in; asthma exacerbation during run-in; } \\
\text { use of systemic corticosteroids/respiratory infection affecting asthma control within } 30 \\
\text { days of study entry }\end{array}$ \\
\hline Interventions & $\begin{array}{l}\text { 1. Combination fluticasone and salmeterol } 250 / 50 \mathrm{mcg} \text { bid. BDP equivalent } 1000 \mathrm{mcg} \\
\text { 2. Combination budesonide and formoterol } 400 / 12 \mathrm{mcg} \text { bid. BDP equivalent } 800 \mathrm{mcg} \\
\text { 3. Combination budesonide/formoterol } 200 / 6 \mathrm{mcg} \text { bid (plus additional puffs as required) } \\
\text { DELIVERY DEVICE: FPS: MDI; BDF: DPI } \\
\text { TREATMENT PERIOD: } 24 \text { weeks } \\
\text { RUN-IN: } 2 \text { weeks - regular ICS therapy plus terbutaline prn } \\
\text { RESCUE: Terbutaline }\end{array}$ \\
\hline
\end{tabular}

Outcomes

Primary outcome: Time to first severe exacerbation

Secondary outcomes: Exacerbations; lung function (FEV1; diary card PEF); rescue medication use; symptom scores"

Notes

Dose adjustment criteria: Symptoms and rescue medication use determined whether treatment should be increased. If absence of symptoms \& rescue medication use $(>/=6$ puffs/d or nocturnal symptoms) then maintenance treatment was stepped down Study sponsors: AstraZeneca

\section{Risk of bias}

\section{Description}


COMPASS (Continued)

\begin{tabular}{|c|c|c|}
\hline Adequate sequence generation? & Yes & $\begin{array}{l}\text { 'The randomisation schedule was com- } \\
\text { puter-generated at AstraZeneca Research } \\
\text { and Development, Charnwood, UK. } \\
\text { Within each centre, patients were ran- } \\
\text { domised strictly sequentially as they be- } \\
\text { came eligible.' }\end{array}$ \\
\hline Allocation concealment? & Yes & $\begin{array}{l}\text { Third party not involved in the primary } \\
\text { study. } \\
\text { 'Individual treatment codes and code en- } \\
\text { velopes } \\
\text { (indicating the treatment allocation for } \\
\text { each } \\
\text { randomised patient) were provided, but } \\
\text { code envelopes were to be opened only in } \\
\text { case of medical emergencies.' }\end{array}$ \\
\hline $\begin{array}{l}\text { Blinding? } \\
\text { OCS treated exacerbations \& hospitalisa- } \\
\text { tion }\end{array}$ & Yes & $\begin{array}{l}\text { Participants and investigators blinded to } \\
\text { treatment group assignment. Blinding } \\
\text { achieved with treble-dummy design; par- } \\
\text { ticipants given three devices (two matched } \\
\text { for maintenance administration of drug } \\
\text { and one as reliever) }\end{array}$ \\
\hline $\begin{array}{l}\text { Incomplete outcome data addressed? } \\
\text { OCS treated exacerbations }\end{array}$ & Unclear & $\begin{array}{l}\text { ITT analysis described. Explicit details of } \\
\text { how withdrawals handled were not de- } \\
\text { scribed }\end{array}$ \\
\hline $\begin{array}{l}\text { Incomplete outcome data addressed? } \\
\text { Hospital admission }\end{array}$ & Unclear & $\begin{array}{l}\text { ITT analysis described. Explicit details of } \\
\text { how withdrawals handled were not de- } \\
\text { scribed }\end{array}$ \\
\hline Free of selective reporting? & Yes & Unable to ascertain this reliably. \\
\hline Free of other bias? & Yes & \\
\hline
\end{tabular}

EXCEL

Methods

Randomised, parallel group trial. Double-blind, double-dummy design

178 centres in 18 countries.

Description of withdrawals:

Stated

$\begin{array}{ll}\text { Participants } & \text { N SCREENED: } 1769 \\ & \text { N RANDOMISED: } 1397 \text { (FPS: 694; BDF: 697) } \\ \text { N COMPLETED: } 1258 \\ \mathrm{M}=595 \\ \mathrm{~F}=796\end{array}$

Combination fluticasone and salmeterol versus fixed dose combination budesonide and formoterol for chronic asthma in adults and 
EXCEL (Continued)

\begin{tabular}{|c|c|}
\hline & $\begin{array}{l}\text { MEAN AGE: } 46 \\
\text { BASELINE CHARACTERISTICS: } \\
\text { FEV1 predicted: } 79 \% ; 353 \mathrm{~L} / \mathrm{min} \text { am PEF } \\
\text { INCLUSION CRITERIA: } \\
>18 \text { years; clinical history of asthma ( }>6 \text { months); } 1000-2000 \mathrm{mcg} / \mathrm{d} \text { BDP equivalent; } \\
\text { reversibility of } 12 \% \& 200 \mathrm{~mL} \text { or more post SABA; } 2 \text { or more episodes of asthma during } \\
\text { day/night on } 4 \text { of last } 7 \text { days of run-in. } \\
\text { EXCLUSION: } \\
\text { Upper/lower RTI; hospitalisation with asthma in } 4 \text { weeks prior to baseline visit; oral } \\
\text { steroids within } 4 \text { weeks/depot steroids within } 12 \text { weeks of baseline visit; FEV1 }<50 \% \\
\text { predicted; smoking history of }>10 \text { pack years }\end{array}$ \\
\hline Interventions & $\begin{array}{l}\text { 1. Combination fluticasone and salmeterol } 250 / 50 \mathrm{mcg} \text { bid (+ placebo turbuhaler). BDP } \\
\text { equivalent } 1000 \mathrm{mcg} \\
\text { 2. Combination budesonide and formoterol } 400 / 12 \mathrm{mcg} \text { bid (+ placebo Diskus). BDP } \\
\text { equivalent } 800 \mathrm{mcg} \\
\text { DELIVERY: FPS: Diskus; BDF: Turbuhaler } \\
\text { TREATMENT PERIOD: } 24 \text { weeks } \\
\text { RUN-IN: } \\
\text { ICS + salbutamol prn ( } 2 \text { weeks) } \\
\text { RESCUE: Salbutamol }\end{array}$ \\
\hline Outcomes & $\begin{array}{l}\text { Primary outcome: rate of exacerbations } \\
\text { Secondary outcomes: } \\
\text { Exacerbations (use of oral steroids; hospitalisations); asthma symptoms; rescue medica- } \\
\text { tion use; am PEF; pm PEF; FEV1; withdrawals; adverse events }\end{array}$ \\
\hline Notes & Study sponsors: GSK \\
\hline
\end{tabular}

Risk of bias

\begin{tabular}{l|l|l}
\hline Item & Authors' judgement & Description \\
\hline Adequate sequence generation? & Yes & $\begin{array}{l}\text { 'Patients were assigned to study treatment } \\
\text { in accordance with the randomisation } \\
\text { schedule from the Interactive Voice } \\
\text { Recognition System, which was part of the } \\
\text { GSK } \\
\text { System for the Central Allocation of Med- } \\
\text { ication.' }\end{array}$ \\
\hline Allocation concealment? & Yes & $\begin{array}{l}\text { Third party not involved with primary } \\
\text { study }\end{array}$ \\
\hline $\begin{array}{l}\text { Blinding? } \\
\text { OCS treated exacerbations } \& \text { hospitalisa- } \\
\text { tion }\end{array}$ & Yes & $\begin{array}{l}\text { All treatment packs contained both Diskus/ } \\
\text { Accuhaler and Turbuhaler devices (ei- } \\
\text { ther active Diskus/Accuhaler+placebo Tur- } \\
\text { buhaler, or active Turbuhaler+placebo } \\
\text { Diskus/Accuhaler) and looked identical }\end{array}$
\end{tabular}


EXCEL (Continued)

\begin{tabular}{|c|c|c|}
\hline $\begin{array}{l}\text { Incomplete outcome data addressed? } \\
\text { OCS treated exacerbations }\end{array}$ & Unclear & $\begin{array}{l}\text { ITT analysis described. Explicit details of } \\
\text { how withdrawals handled were not de- } \\
\text { scribed }\end{array}$ \\
\hline $\begin{array}{l}\text { Incomplete outcome data addressed? } \\
\text { Hospital admission }\end{array}$ & Unclear & $\begin{array}{l}\text { ITT analysis described. Explicit details of } \\
\text { how withdrawals handled were not de- } \\
\text { scribed }\end{array}$ \\
\hline Free of selective reporting? & Unclear & Unable to ascertain this reliably \\
\hline Free of other bias? & Yes & \\
\hline
\end{tabular}

\section{SAM40048}

\begin{tabular}{|c|c|}
\hline Methods & $\begin{array}{l}\text { Randomised, parallel group trial. Double-blind, double dummy design } \\
27 \text { centres in Germany. } \\
\text { Description of withdrawals: } \\
\text { Stated }\end{array}$ \\
\hline Participants & $\begin{array}{l}\text { N SCREENED: Not reported } \\
\text { N RANDOMISED: } 248 \text { (ITT population: } 241 \text { ) } \\
\text { N COMPLETED: } 235 \\
\text { M=102 (based on ITT) } \\
\text { F= } 139 \text { (based on ITT) } \\
\text { MEAN AGE: } 48 \\
\text { BASELINE CHARACTERISTICS: FEV1 predicted: } 65 \% \text {; am PEF } 310 \mathrm{~L} / \mathrm{min} \\
\text { INCLUSION CRITERIA: } \\
\text { 'Moderate' asthma; >18 years; FEV1 50-80\% predicted; >15\% reversibility; ICS dose } \\
1000 \text { mcg/d (BDP equivalent); symptomatic (symptom score of } 1 \text { on } 7 \text { days of the run- } \\
\text { in period). } \\
\text { EXCLUSION CRITERIA: Exacerbations/emergency visits during 4-week pre-study } \\
\text { period; smoking (>20 cigarettes/d) }\end{array}$ \\
\hline Interventions & $\begin{array}{l}\text { 1. Combination fluticasone and salmeterol } 250 / 50 \mathrm{mcg} \text { bid + placebo Turbohaler. BDP } \\
\text { equivalent } 1000 \mathrm{mcg} \\
\text { 2. Combination budesonide and formoterol } 200 / 6 \mathrm{mcg} \text { bid + placebo Diskus inhaler. } \\
\text { BDP equivalent } 400 \mathrm{mcg} \\
\text { DELIVERY DEVICE: FPS: Diskus; BDF: Turbohaler } \\
\text { TREATMENT PERIOD: } 12 \text { weeks } \\
\text { RUN-IN: } 2 \text { weeks (treatment not clear) } \\
\text { RESCUE: Not reported }\end{array}$ \\
\hline Outcomes & $\begin{array}{l}\text { Primary outcome: FEV1 predicted } \\
\text { Secondary outcomes: Morning PEF; evening PEF; daytime and evening asthma symp- } \\
\text { toms; symptom-free days; rescue medication-free days; safety }\end{array}$ \\
\hline Notes & Study sponsors: GSK \\
\hline
\end{tabular}


SAM40048 (Continued)

\begin{tabular}{|c|c|c|}
\hline Item & Authors' judgement & Description \\
\hline Adequate sequence generation? & Unclear & Information not available. \\
\hline Allocation concealment? & Unclear & Not reported \\
\hline $\begin{array}{l}\text { Blinding? } \\
\text { OCS treated exacerbations \& hospitalisa- } \\
\text { tion }\end{array}$ & Yes & $\begin{array}{l}\text { Participants and investigators blinded to } \\
\text { treatment group allocation with double- } \\
\text { dummy design }\end{array}$ \\
\hline $\begin{array}{l}\text { Incomplete outcome data addressed? } \\
\text { OCS treated exacerbations }\end{array}$ & Unclear & $\begin{array}{l}\text { ITT analysis described. Explicit details of } \\
\text { how withdrawals handled were not de- } \\
\text { scribed }\end{array}$ \\
\hline $\begin{array}{l}\text { Incomplete outcome data addressed? } \\
\text { Hospital admission }\end{array}$ & Unclear & $\begin{array}{l}\text { ITT analysis described. Explicit details of } \\
\text { how withdrawals handled were not de- } \\
\text { scribed }\end{array}$ \\
\hline Free of selective reporting? & Unclear & Unable to ascertain this reliably \\
\hline Free of other bias? & Yes & \\
\hline
\end{tabular}

ATS: American Thoracic Society; BDF: budesonide/formoterol; BDP: Beclomethasone; BID: twice daily; DPI: Dry powder inhaler; FEV1: Forced expiratory volume in 1 second; FPS: Fluticasone/salmeterol combination; ICS: inhaled corticosteroid; MDI: metered dose inhaler; PEF: peak expiratory flow; RTI: Respiratory tract infection; SABA: Short-acting beta-agonist.

Characteristics of excluded studies [ordered by study ID]

\begin{tabular}{ll}
\hline Study & Reason for exclusion \\
\hline Adachi 2008 & Study compared combination FP/SAL with FP and theophylline. \\
\hline AHEAD & Study comparing FP/SAL with BUD/F as an adjustable dosing strategy \\
\hline ALLIANCE & Combinations assessed not relevant to this review. \\
\hline Ambrose 2007 & Study compared different doses of BUD/F. No comparison with FP/SAL \\
\hline Bleecker 2007 & Study randomised participants to FP/SAL or SAL. No comparison with BUD/F \\
\hline Brambilla 2003 & Separate inhalers: Formoterol versus Salmeterol as add on to ICS
\end{tabular}


(Continued)

\begin{tabular}{ll}
\hline CONCEPT & Assessment of combination FP/SAL against BUD/F given as an adjustable dosing strategy \\
\hline Creemers 2002 & Study summarised data from two studies comparing BDF with ICS alone \\
\hline EDICT & Combination FPS versus BUD/F given via separate inhalers. \\
\hline Hampel 2007 & Report of two crossover studies: ineligible design. \\
\hline Jenkins 2000 & Study assessed FPS with ICS alone. \\
\hline Kaik 2002 & Separate F and BUD preparations versus combination FPS. \\
\hline Lee 2003 & Crossover design. \\
\hline Lotväll 2002 & Summary of two crossover studies. \\
\hline Palmqvist 2001 & Crossover design. \\
\hline SAM40042 & Crossover design. \\
\hline SAM40047 & Crossover design. \\
\hline SAM40062 & Crossover design. \\
\hline Vogelmeier 2005 & Comparison of FP/SAL with BUD/F as maintenance and relief. \\
\hline
\end{tabular}


DATA AND ANALYSES

Comparison 1. Combination fluticasone/salmeterol versus budesonide/formoterol

\begin{tabular}{|c|c|c|c|c|}
\hline Outcome or subgroup title & $\begin{array}{l}\text { No. of } \\
\text { studies }\end{array}$ & $\begin{array}{c}\text { No. of } \\
\text { participants }\end{array}$ & Statistical method & Effect size \\
\hline $\begin{array}{l}1 \text { Participants experiencing } \\
\text { exacerbations requiring oral } \\
\text { steroid treatment }\end{array}$ & 4 & 4949 & Odds Ratio (M-H, Fixed, 95\% CI) & $0.89[0.74,1.07]$ \\
\hline $\begin{array}{l}2 \text { Participants experiencing } \\
\text { exacerbations requiring } \\
\text { admission to hospital }\end{array}$ & 4 & 4879 & Odds Ratio (M-H, Fixed, 95\% CI) & $1.29[0.68,2.47]$ \\
\hline $\begin{array}{l}3 \text { Asthma-related serious adverse } \\
\text { event }\end{array}$ & 3 & 4054 & Odds Ratio (M-H, Fixed, 95\% CI) & $1.47[0.75,2.86]$ \\
\hline $\begin{array}{l}4 \text { Participants experiencing } \\
\text { exacerbations requiring ED } \\
\text { visit/hospitalisation }\end{array}$ & 4 & 4861 & Odds Ratio (M-H, Fixed, 95\% CI) & $1.30[0.94,1.80]$ \\
\hline 5 Change in FEV1 & 4 & 4845 & L (Fixed, 95\% CI) & Not estimable \\
\hline 6 Change in FEV1 predicted (\%) & 1 & & Mean Difference (IV, Fixed, 95\% CI) & Totals not selected \\
\hline 7 Change in am PEF & 5 & 5101 & L/min (Fixed, 95\% CI) & $2.24[-0.24,4.73]$ \\
\hline 8 Change in pm PEF & 4 & 4299 & $\mathrm{~L} / \mathrm{min}$ (Fixed, 95\% CI) & $0.25[-0.80,1.30]$ \\
\hline 9 Change in daytime symptoms & 3 & 3464 & Symptoms (Fixed, 95\% CI) & $-0.02[-0.06,0.03]$ \\
\hline 10 Change in symptom-free days & 2 & 3027 & Symptoms (Fixed, 95\% CI) & $1.25[-1.18,3.67]$ \\
\hline $\begin{array}{l}11 \text { Change in nocturnal } \\
\text { awakenings }\end{array}$ & 1 & & Symptoms (Fixed, 95\% CI) & Totals not selected \\
\hline $\begin{array}{l}12 \text { Change in rescue medication } \\
\text { use }\end{array}$ & 3 & 3469 & Puffs/d (Fixed, 95\% CI) & $-0.06[-0.13,0.02]$ \\
\hline 13 Withdrawals & 5 & 5082 & Odds Ratio (M-H, Fixed, 95\% CI) & $0.97[0.78,1.20]$ \\
\hline 14 Withdrawals (adverse events) & 5 & 5082 & Odds Ratio (M-H, Fixed, 95\% CI) & $0.94[0.60,1.46]$ \\
\hline 15 Withdrawals (lack of efficacy) & 1 & & Odds Ratio (M-H, Fixed, 95\% CI) & Totals not selected \\
\hline 16 Adverse events & 2 & 1644 & Odds Ratio (M-H, Fixed, 95\% CI) & $1.08[0.89,1.31]$ \\
\hline 17 Headache & 4 & 2916 & Odds Ratio (M-H, Fixed, 95\% CI) & $1.08[0.82,1.43]$ \\
\hline 18 Candidiasis & 2 & 1272 & Odds Ratio (M-H, Fixed, 95\% CI) & $1.64[0.68,4.00]$ \\
\hline 19 Dysphonia & 3 & 2669 & Odds Ratio (M-H, Fixed, 95\% CI) & $1.45[0.87,2.43]$ \\
\hline $\begin{array}{l}20 \text { Upper respiratory tract } \\
\text { infection }\end{array}$ & 2 & 1644 & Odds Ratio (M-H, Fixed, 95\% CI) & $1.09[0.81,1.47]$ \\
\hline 21 Rhinitis & 1 & & Odds Ratio (M-H, Fixed, 95\% CI) & Totals not selected \\
\hline 22 Throat irritation & 2 & 1644 & Odds Ratio (M-H, Fixed, 95\% CI) & $1.39[0.82,2.35]$ \\
\hline 23 Cough & 1 & & Odds Ratio (M-H, Fixed, 95\% CI) & Totals not selected \\
\hline 24 Tremor & 1 & & Odds Ratio (M-H, Fixed, 95\% CI) & Totals not selected \\
\hline
\end{tabular}


Analysis I.I. Comparison I Combination fluticasone/salmeterol versus budesonide/formoterol, Outcome I Participants experiencing exacerbations requiring oral steroid treatment.

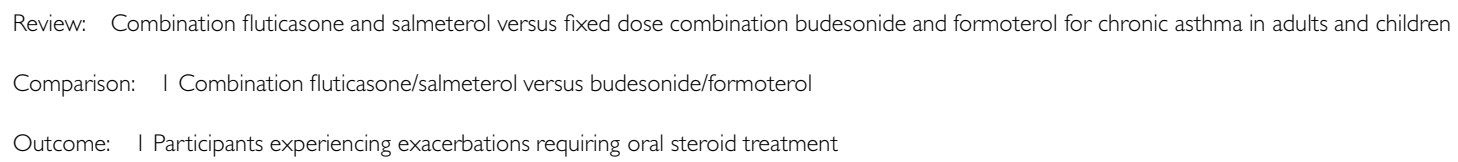

\begin{tabular}{|c|c|c|c|c|c|}
\hline \multirow[t]{2}{*}{ Study or subgroup } & FP/SAL & $\mathrm{BUD} / \mathrm{F}$ & Odds Ratio & Weight & Odds Ratio \\
\hline & $\mathrm{n} / \mathrm{N}$ & $n / N$ & M-H,Fixed,95\% Cl & & M-H,Fixed,95\% Cl \\
\hline Aalbers 2004 & $30 / 219$ & $33 / 215$ & - & $12.2 \%$ & $0.88[0.51,1.49]$ \\
\hline Busse 2008 & $37 / 404$ & $37 / 422$ & $\longrightarrow$ & $13.9 \%$ & $1.05[0.65,1.69]$ \\
\hline COMPASS & $109 / 1199$ & 108/1099 & 畐 & $43.5 \%$ & $0.92[0.69,1.21]$ \\
\hline EXCEL & $63 / 694$ & $79 / 697$ & $\rightarrow$ & $30.4 \%$ & $0.78[0.55,1.11]$ \\
\hline
\end{tabular}

Total (95\% CI) $2516 \quad 2433$

Total events: 239 (FP/SAL), 257 (BUD/F)

Heterogeneity: $\mathrm{Chi}^{2}=1.04, \mathrm{df}=3(\mathrm{P}=0.79) ; \mathrm{I}^{2}=0.0 \%$

Test for overall effect: $Z=1.24(P=0.22)$

$$
\begin{aligned}
& \begin{array}{lllllll}
0.1 & 0.2 & 0.5 & 1 & 2 & 5 & 10
\end{array} \\
& \text { Favours FP/SAL Favours BUD/F }
\end{aligned}
$$

Analysis I.2. Comparison I Combination fluticasone/salmeterol versus budesonide/formoterol, Outcome 2 Participants experiencing exacerbations requiring admission to hospital.

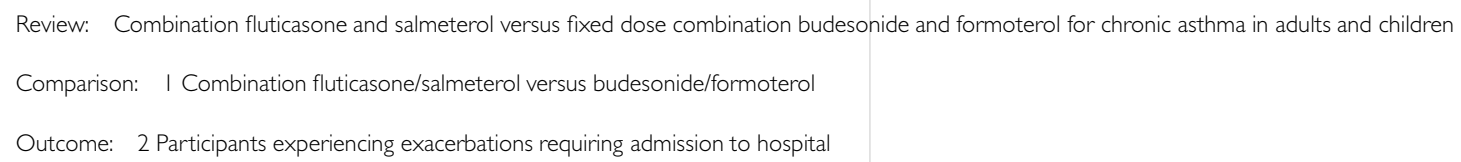

\begin{tabular}{|c|c|c|c|c|c|}
\hline \multirow[t]{2}{*}{ Study or subgroup } & FP/SAL & $\mathrm{B} \cup \mathrm{D} / \mathrm{F}$ & Odds Ratio & \multirow[t]{2}{*}{ Weight } & \multirow{2}{*}{$\begin{array}{r}\text { Odds Ratio } \\
\mathrm{M}-\mathrm{H}, \text { Fixed,95\% Cl}\end{array}$} \\
\hline & $\mathrm{n} / \mathrm{N}$ & $n / N$ & M-H,Fixed,95\% Cl & & \\
\hline Aalbers 2004 & $0 / 219$ & $1 / 215$ & - & $9.2 \%$ & $0.33[0.01,8.04]$ \\
\hline Busse 2008 & $2 / 404$ & 1/422 & $\rightarrow$ & $5.9 \%$ & $2.09[0.19,23.19]$ \\
\hline COMPASS & $15 / 1123$ & $13 / 1105$ & & $78.8 \%$ & $1.14[0.54,2.40]$ \\
\hline EXCEL & $4 / 694$ & $1 / 697$ & $\longrightarrow$ & $6.0 \%$ & $4.03[0.45,36.19]$ \\
\hline Total (95\% CI) & 2440 & 2439 & - & $100.0 \%$ & $1.29[0.68,2.47]$ \\
\hline \multicolumn{6}{|c|}{ Total events: 2 I (FP/SAL), I6 (BUD/F) } \\
\hline \multicolumn{6}{|c|}{ Heterogeneity: $\mathrm{Chi}^{2}=2.0 \mathrm{I}, \mathrm{df}=3(\mathrm{P}=0.57) ; \mathrm{I}^{2}=0.0 \%$} \\
\hline \multicolumn{6}{|c|}{ Test for overall effect: $Z=0.79(P=0.43)$} \\
\hline
\end{tabular}


Analysis I.3. Comparison I Combination fluticasone/salmeterol versus budesonide/formoterol, Outcome 3 Asthma-related serious adverse event.

Review: Combination fluticasone and salmeterol versus fixed dose combination budesonide and formoterol for chronic asthma in adults and children

Comparison: I Combination fluticasone/salmeterol versus budesonide/formoterol

Outcome: 3 Asthma-related serious adverse event

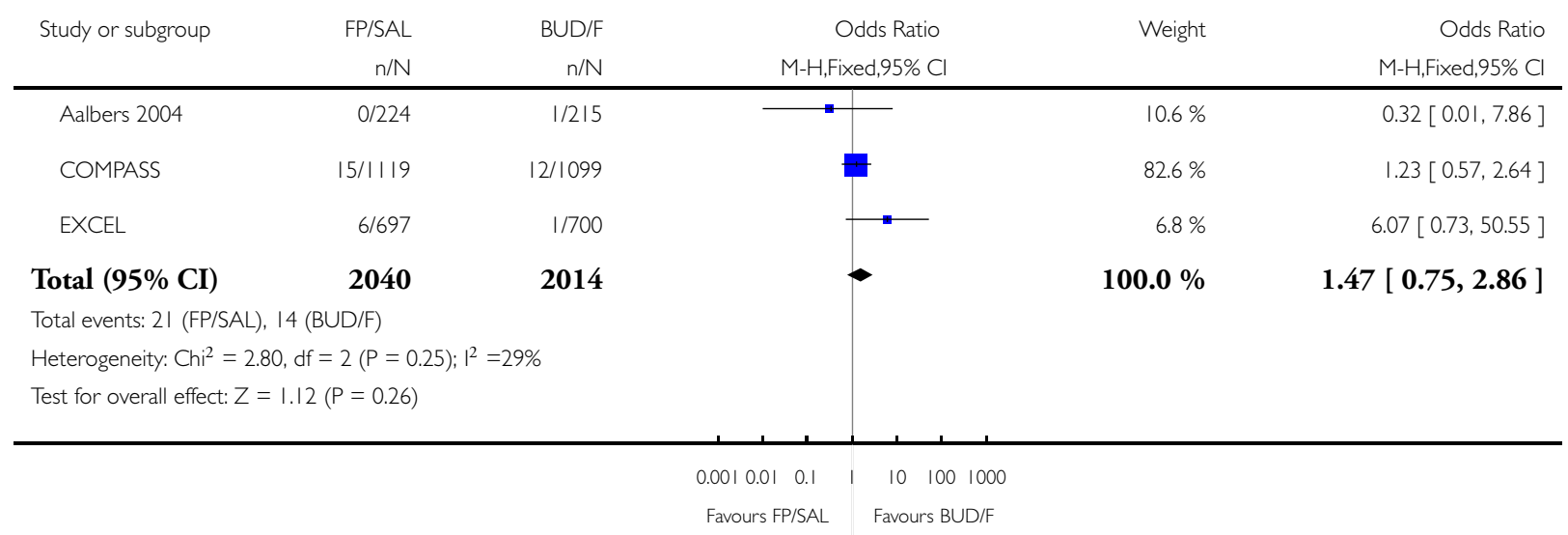


Analysis I.4. Comparison I Combination fluticasone/salmeterol versus budesonide/formoterol, Outcome 4 Participants experiencing exacerbations requiring ED visit/hospitalisation.

Review: Combination fluticasone and salmeterol versus fixed dose combination budesonide and formoterol for chronic asthma in adults and children

Comparison: I Combination fluticasone/salmeterol versus budesonide/formoterol

Outcome: 4 Participants experiencing exacerbations requiring ED visit/hospitalisation

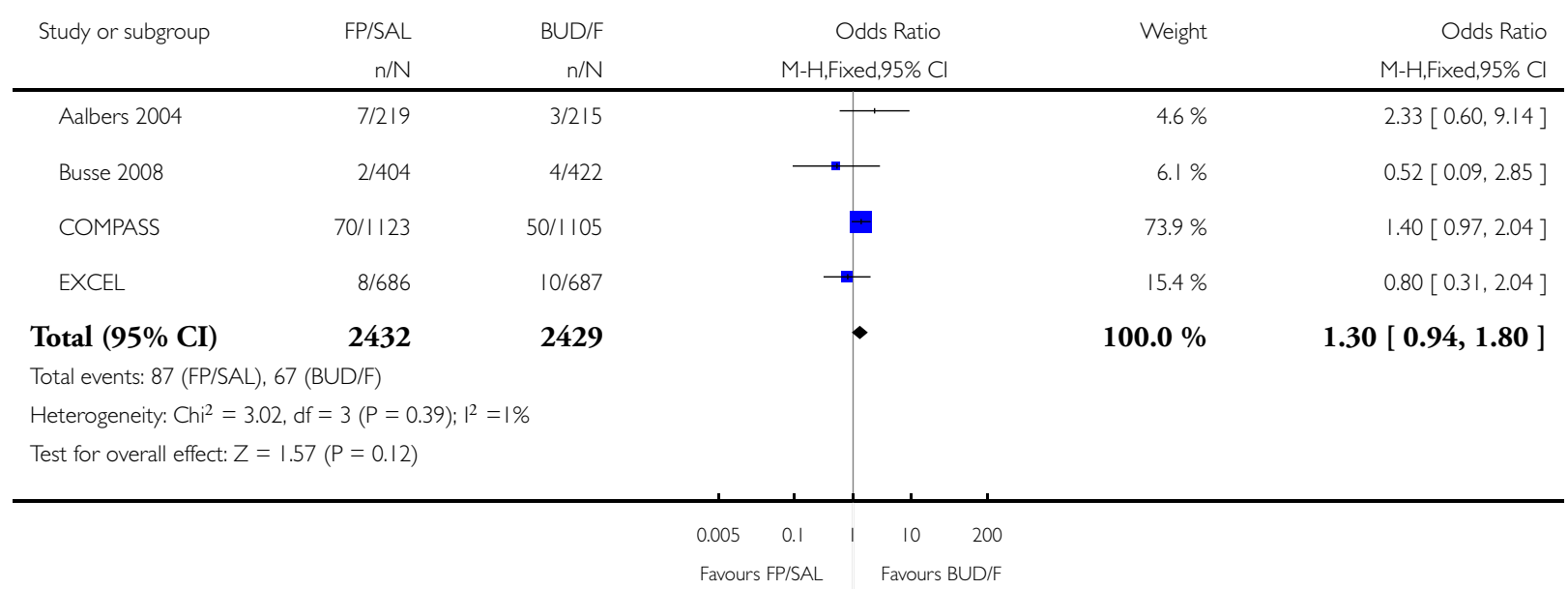

Analysis I.5. Comparison I Combination fluticasone/salmeterol versus budesonide/formoterol, Outcome 5 Change in FEVI.

Review: Combination fluticasone and salmeterol versus fixed dose combination budesonide and formoterol for chronic asthma in adults and children

Comparison: I Combination fluticasone/salmeterol versus budesonide/formoterol

Outcome: 5 Change in FEVI

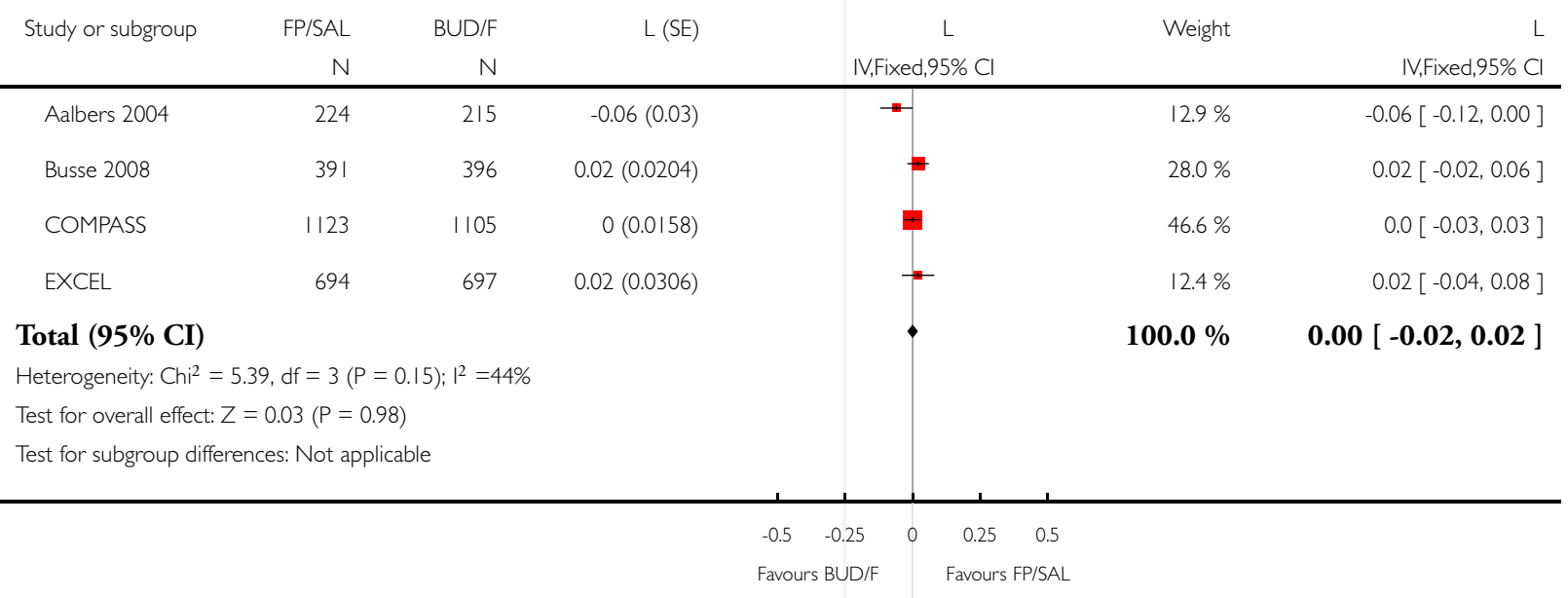

Combination fluticasone and salmeterol versus fixed dose combination budesonide and formoterol for chronic asthma in adults and 


\section{Analysis I.6. Comparison I Combination fluticasone/salmeterol versus budesonide/formoterol, Outcome 6 Change in FEVI predicted (\%).}

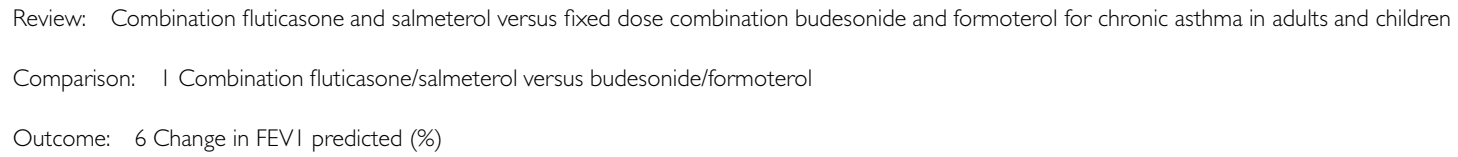

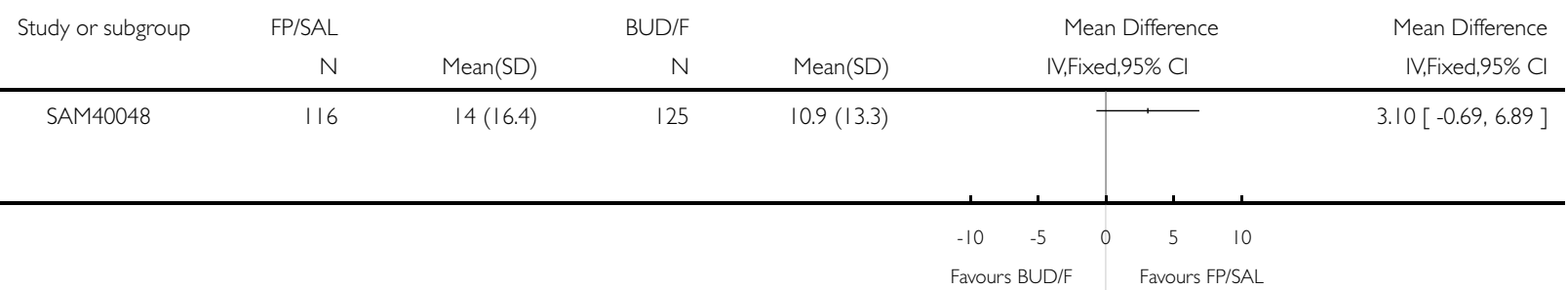

\section{Analysis I.7. Comparison I Combination fluticasone/salmeterol versus budesonide/formoterol, Outcome 7} Change in am PEF.

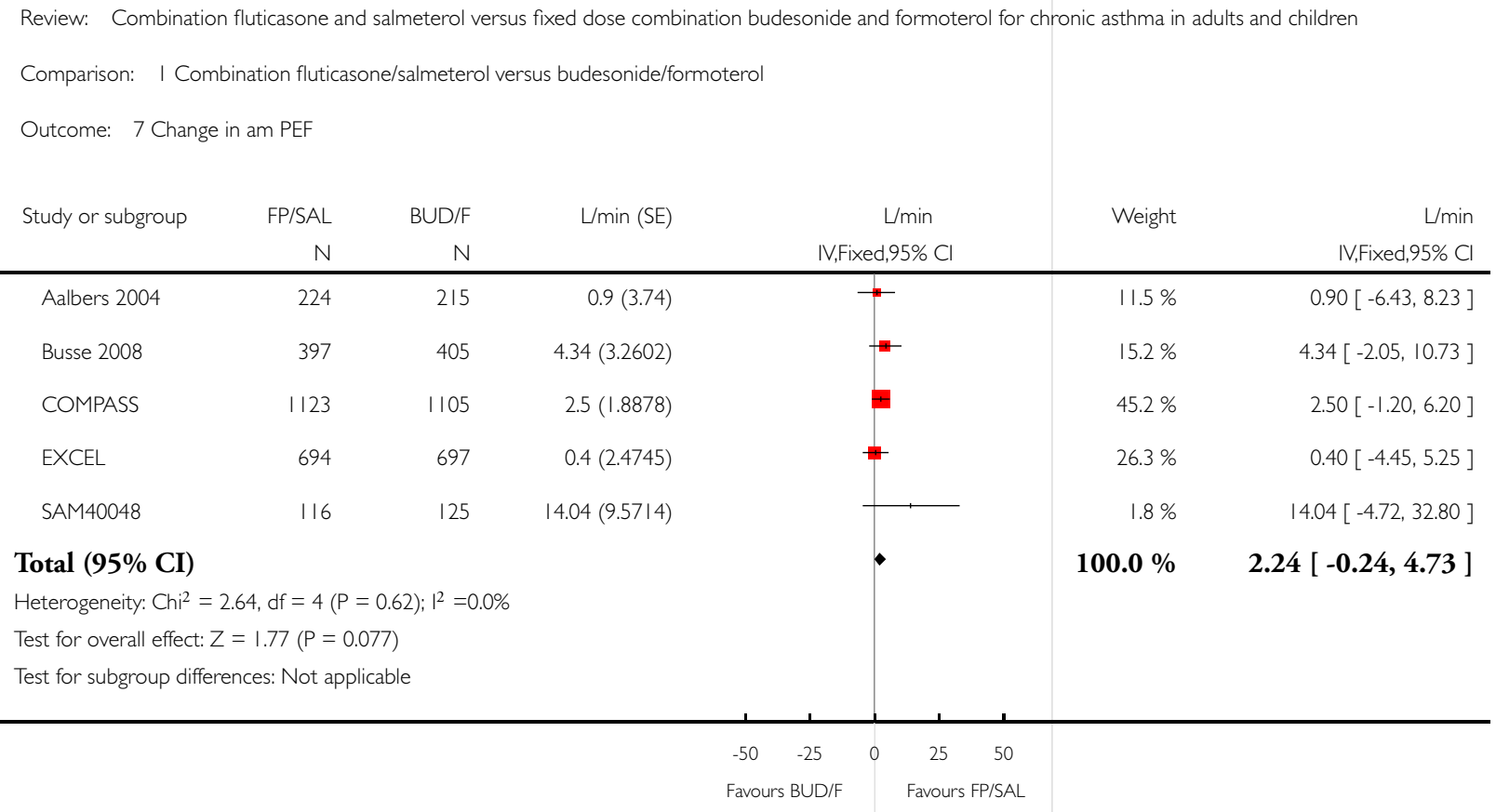

Combination fluticasone and salmeterol versus fixed dose combination budesonide and formoterol for chronic asthma in adults and 
Analysis I.8. Comparison I Combination fluticasone/salmeterol versus budesonide/formoterol, Outcome 8 Change in pm PEF.

Review: Combination fluticasone and salmeterol versus fixed dose combination budesonide and formoterol for chronic asthma in adults and children

Comparison: I Combination fluticasone/salmeterol versus budesonide/formoterol

Outcome: 8 Change in Pm PEF

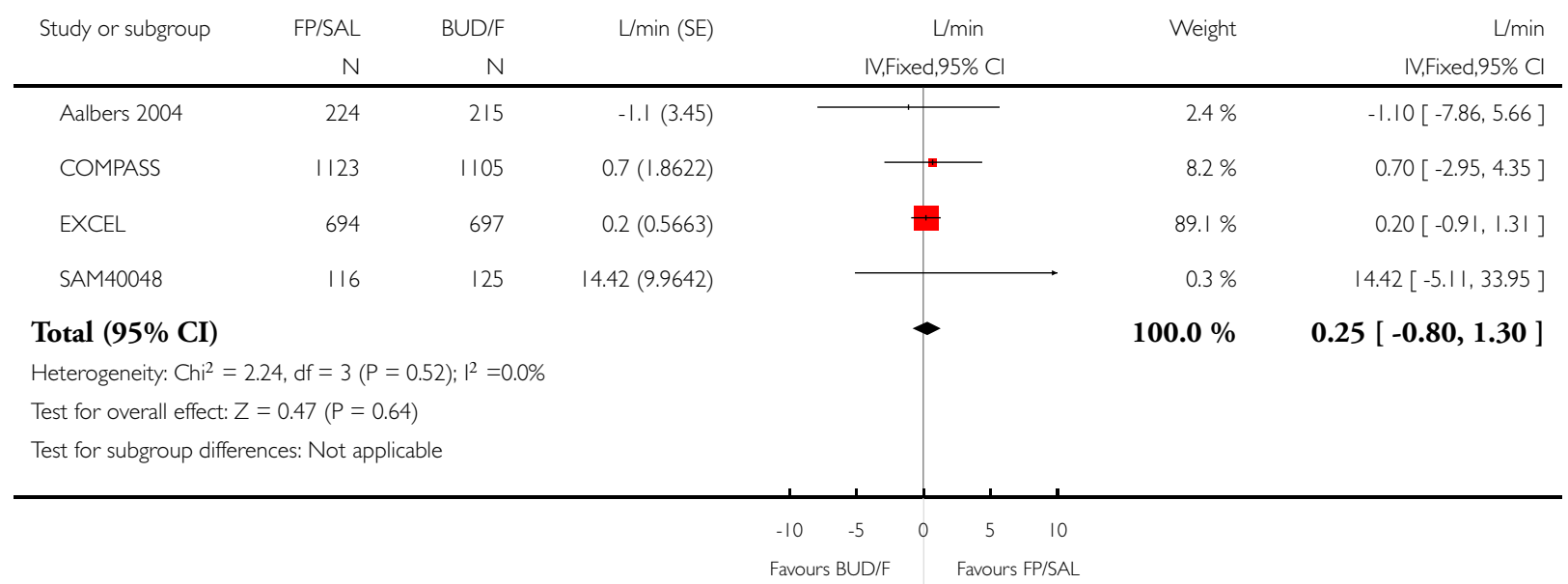


Analysis I.9. Comparison I Combination fluticasone/salmeterol versus budesonide/formoterol, Outcome 9 Change in daytime symptoms.

Review: Combination fluticasone and salmeterol versus fixed dose combination budesonide and formoterol for chronic asthma in adults and children

Comparison: I Combination fluticasone/salmeterol versus budesonide/formoterol

Outcome: 9 Change in daytime symptoms

\begin{tabular}{|c|c|c|c|c|c|c|}
\hline \multirow[t]{2}{*}{ Study or subgroup } & FP/SAL & $\mathrm{BUD} / \mathrm{F}$ & Symptoms (SE) & Symptoms & Weight & Symptoms \\
\hline & $\mathrm{N}$ & $\mathrm{N}$ & & IV,Fixed,95\% Cl & & IV,Fixed,95\% Cl \\
\hline Aalbers 2004 & 224 & 215 & $-0.05(0.06)$ & $\rightarrow$ & $14.1 \%$ & $-0.05[-0.17,0.07]$ \\
\hline Busse 2008 & 395 & 402 & $0.02(0.0357)$ & + & $39.8 \%$ & $0.02[-0.05,0.09]$ \\
\hline COMPASS & 1123 & 1105 & $-0.04(0.0332)$ & 풀 & $46.1 \%$ & $-0.04[-0.11,0.03]$ \\
\hline
\end{tabular}

Total (95\% CI)

$100.0 \% \quad-0.02[-0.06,0.03]$

Heterogeneity: Chi $^{2}=1.86, \mathrm{df}=2(\mathrm{P}=0.40) ;\left.\right|^{2}=0.0 \%$

Test for overall effect: $Z=0.78(P=0.44)$

Test for subgroup differences: Not applicable

$\begin{array}{ccccc}-1 & -0.5 & 0 & 0.5 & \text { । } \\ \text { Favours FP/SAL } & & \text { Favours BUD/F }\end{array}$

Analysis I.10. Comparison I Combination fluticasone/salmeterol versus budesonide/formoterol, Outcome 10 Change in symptom-free days.

Review: Combination fluticasone and salmeterol versus fixed dose combination budesonide and formoterol for chronic asthma in adults and children

Comparison: I Combination fluticasone/salmeterol versus budesonide/formoterol

Outcome: 10 Change in symptom-free days

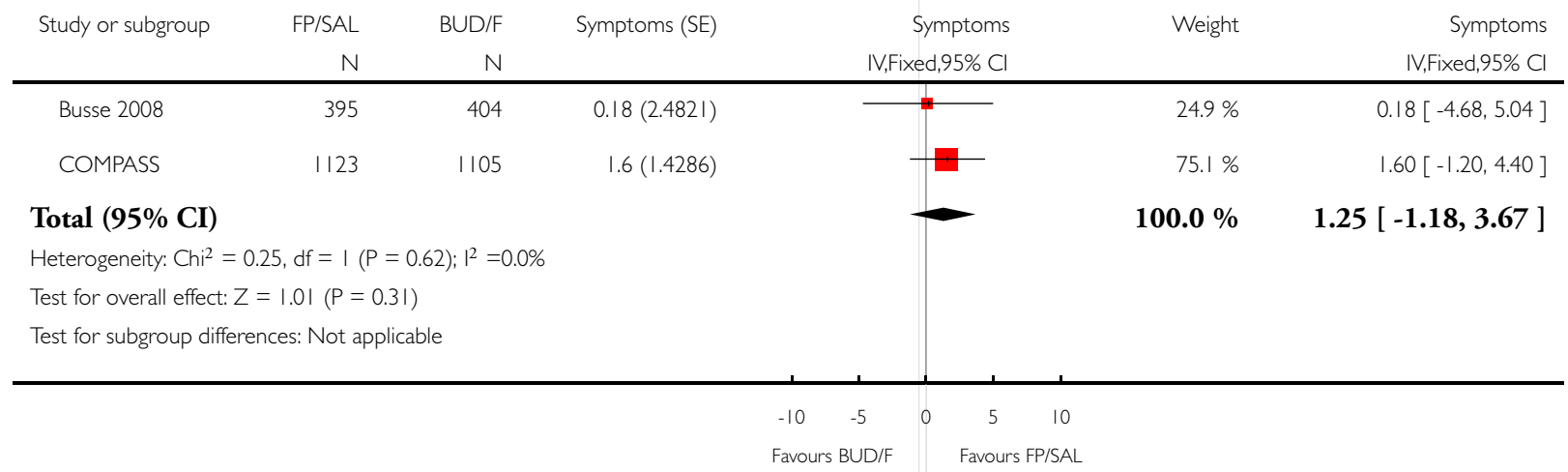


Analysis I.I I. Comparison I Combination fluticasone/salmeterol versus budesonide/formoterol, Outcome I I Change in nocturnal awakenings.

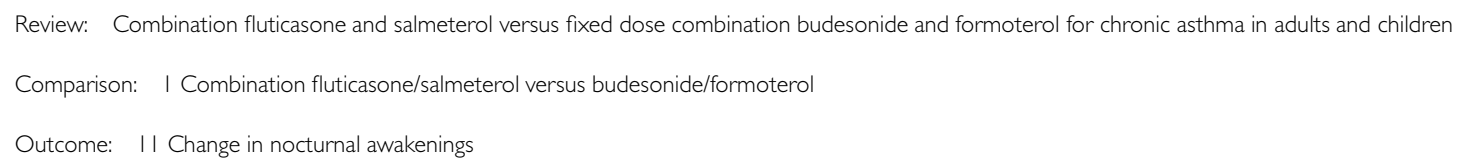

\begin{tabular}{|c|c|c|c|c|c|}
\hline & $\mathrm{N}$ & $\mathrm{N}$ & & IV,Fixed,95\% Cl & IV,Fixed,95\% Cl \\
\hline COMPASS & 1123 & 1105 & $-0.2(0.8163)$ & 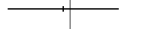 & $-0.20[-1.80,1.40$ \\
\hline
\end{tabular}

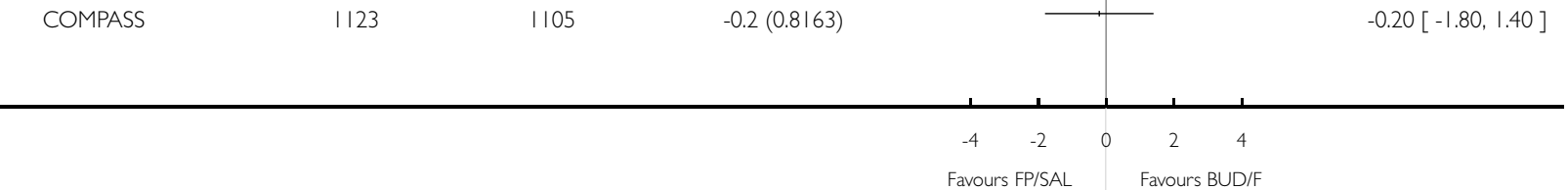

\section{Analysis I.I2. Comparison I Combination fluticasone/salmeterol versus budesonide/formoterol, Outcome} 12 Change in rescue medication use.

Review: Combination fluticasone and salmeterol versus fixed dose combination budesonide and formoterol for chronic asthma in adults and children

Comparison: I Combination fluticasone/salmeterol versus budesonide/formoterol

Outcome: 12 Change in rescue medication use

\begin{tabular}{|c|c|c|c|c|c|c|}
\hline \multirow[t]{2}{*}{ Study or subgroup } & FP/SAL & $\mathrm{BUD} / \mathrm{F}$ & Puffs/d (SE) & Puffs/d & Weight & Puffs/d \\
\hline & $\mathrm{N}$ & $\mathrm{N}$ & & IV,Fixed,95\% Cl & & IV,Fixed,95\% Cl \\
\hline Aalbers 2004 & 224 & 215 & $-0.03(0.11)$ & $\longrightarrow$ & $12.0 \%$ & $-0.03[-0.25,0.19]$ \\
\hline Busse 2008 & 396 & 406 & $0.07(0.0867)$ & - & $19.3 \%$ & $0.07[-0.10,0.24]$ \\
\hline COMPASS & 1123 & 1105 & $-0.1(0.0459)$ & + & $68.8 \%$ & $-0.10[-0.19,-0.01]$ \\
\hline
\end{tabular}

Total (95\% CI)

Heterogeneity: $\mathrm{Chi}^{2}=3.08, \mathrm{df}=2(\mathrm{P}=0.21) ; 1^{2}=35 \%$

Test for overall effect: $Z=1.55(P=0.12)$

Test for subgroup differences: Not applicable

$100.0 \% \quad-0.06[-0.13,0.02]$ 
Analysis I.13. Comparison I Combination fluticasone/salmeterol versus budesonide/formoterol, Outcome 13 Withdrawals.

Review: Combination fluticasone and salmeterol versus fixed dose combination budesonide and formoterol for chronic asthma in adults and children

Comparison: I Combination fluticasone/salmeterol versus budesonide/formoterol

Outcome: 13 Withdrawals

\begin{tabular}{|c|c|c|c|c|c|}
\hline \multirow[t]{2}{*}{ Study or subgroup } & FP/SAL & $\mathrm{BUD} / \mathrm{F}$ & Odds Ratio & Weight & Odds Ratio \\
\hline & $\mathrm{n} / \mathrm{N}$ & $\mathrm{n} / \mathrm{N}$ & M-H,Fixed,95\% Cl & & M-H,Fixed,95\% Cl \\
\hline Aalbers 2004 & $25 / 224$ & $31 / 215$ & $\because-$ & $16.1 \%$ & $0.75[0.42,1.31]$ \\
\hline Busse 2008 & $37 / 391$ & $37 / 389$ & $\longrightarrow$ & $19.3 \%$ & $0.99[0.62,1.61]$ \\
\hline COMPASS & $45 / 1119$ & $53 / 1099$ & $\rightarrow$ & $29.5 \%$ & $0.83[0.55,1.24]$ \\
\hline EXCEL & $71 / 697$ & $62 / 700$ & & $31.9 \%$ & $1.17[0.82,1.67]$ \\
\hline SAM40048 & $7 / 121$ & $6 / 127$ & & $3.2 \%$ & $1.24[0.40,3.80]$ \\
\hline Total (95\% CI) & 2552 & 2530 & 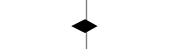 & $100.0 \%$ & $0.97[0.78,1.20]$ \\
\hline \multicolumn{6}{|c|}{ Total events: I 85 (FP/SAL), I 89 (BUD/F) } \\
\hline \multicolumn{6}{|c|}{ Heterogeneity: $\mathrm{Chi}^{2}=2.65, \mathrm{df}=4(\mathrm{P}=0.62) ; \mathrm{I}^{2}=0.0 \%$} \\
\hline \multicolumn{6}{|c|}{ Test for overall effect: $Z=0.30(P=0.76)$} \\
\hline
\end{tabular}

$\begin{array}{lllllll}0.1 & 0.2 & 0.5 & 1 & 2 & 5 & 10\end{array}$

Favours FP/SAL Favours BUD/F 
Analysis I.I4. Comparison I Combination fluticasone/salmeterol versus budesonide/formoterol, Outcome 14 Withdrawals (adverse events).

Review: Combination fluticasone and salmeterol versus fixed dose combination budesonide and formoterol for chronic asthma in adults and children

Comparison: I Combination fluticasone/salmeterol versus budesonide/formoterol

Outcome: 14 Withdrawals (adverse events)

\begin{tabular}{|c|c|c|c|c|c|}
\hline \multirow[t]{2}{*}{ Study or subgroup } & FP/SAL & $\mathrm{BUD} / \mathrm{F}$ & Odds Ratio & Weight & Odds Ratio \\
\hline & $\mathrm{n} / \mathrm{N}$ & $\mathrm{n} / \mathrm{N}$ & M-H,Fixed,95\% Cl & & M-H,Fixed,95\% Cl \\
\hline Aalbers 2004 & $9 / 224$ & $10 / 215$ & $\longrightarrow$ & $24.2 \%$ & $0.86[0.34,2.15]$ \\
\hline Busse 2008 & $5 / 391$ & $5 / 389$ & & $12.2 \%$ & $0.99[0.29,3.46]$ \\
\hline COMPASS & $10 / 1119$ & 13/1099 & $\mathbf{P}$ & $32.2 \%$ & $0.75[0.33,1.73]$ \\
\hline EXCEL & $13 / 697$ & $10 / 700$ & - & $24.2 \%$ & $1.31[0.57,3.01]$ \\
\hline SAM40048 & $2 / 121$ & $3 / 127$ & & $7.1 \%$ & $0.69[0.11,4.23]$ \\
\hline Total (95\% CI) & 2552 & 2530 & & $100.0 \%$ & $0.94[0.60,1.46]$ \\
\hline \multicolumn{6}{|c|}{ Total events: 39 (FP/SAL), 4 I (BUD/F) } \\
\hline \multicolumn{6}{|c|}{ Heterogeneity: $\mathrm{Chi}^{2}=1.04, \mathrm{df}=4(\mathrm{P}=0.90) ; 1^{2}=0.0 \%$} \\
\hline \multicolumn{6}{|c|}{ Test for overall effect: $Z=0.28(P=0.78)$} \\
\hline
\end{tabular}

$\begin{array}{lllllll}0.1 & 0.2 & 0.5 & 1 & 2 & 5 & 10\end{array}$

Favours FP/SAL Favours BUD/F

Analysis I.I5. Comparison I Combination fluticasone/salmeterol versus budesonide/formoterol, Outcome I5 Withdrawals (lack of efficacy).

Review: Combination fluticasone and salmeterol versus fixed dose combination budesonide and formoterol for chronic asthma in adults and children

Comparison: I Combination fluticasone/salmeterol versus budesonide/formoterol

Outcome: 15 Withdrawals (lack of efficacy)

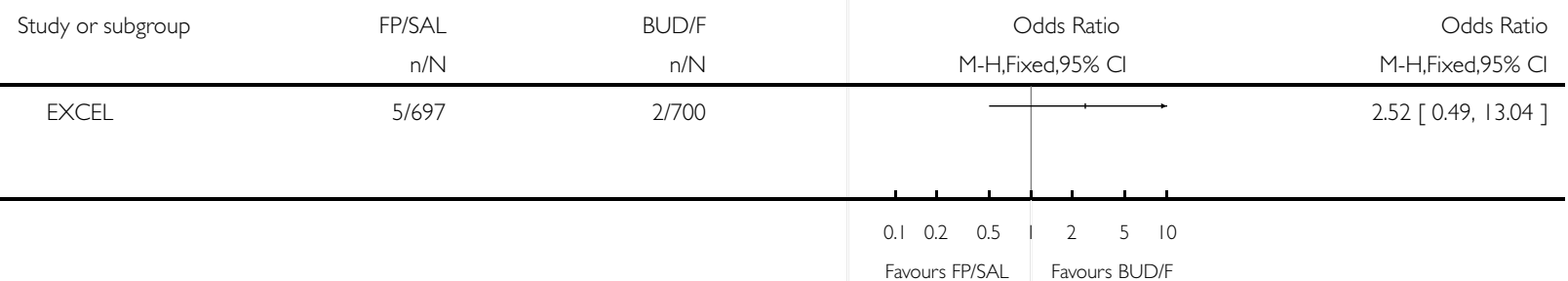


Analysis I.16. Comparison I Combination fluticasone/salmeterol versus budesonide/formoterol, Outcome 16 Adverse events.

Review: Combination fluticasone and salmeterol versus fixed dose combination budesonide and formoterol for chronic asthma in adults and children

Comparison: I Combination fluticasone/salmeterol versus budesonide/formoterol

Outcome: 16 Adverse events

\begin{tabular}{|c|c|c|c|c|c|}
\hline \multirow[t]{2}{*}{ Study or subgroup } & FP/SAL & $\mathrm{BUD} / \mathrm{F}$ & Odds Ratio & \multirow[t]{2}{*}{ Weight } & \multirow{2}{*}{$\begin{array}{r}\text { Odds Ratio } \\
\text { M-H,Fixed,95\% Cl }\end{array}$} \\
\hline & $\mathrm{n} / \mathrm{N}$ & $\mathrm{n} / \mathrm{N}$ & M-H,Fixed,95\% Cl & & \\
\hline EXCEL & $384 / 697$ & $377 / 700$ & & $87.4 \%$ & $1.05[0.85,1.30]$ \\
\hline SAM40048 & $44 / 121$ & $39 / 126$ & - & $12.6 \%$ & $1.27[0.75,2.16]$ \\
\hline Total $(95 \%$ CI $)$ & 818 & 826 & - & $100.0 \%$ & $1.08[0.89,1.31]$ \\
\hline \multicolumn{6}{|c|}{ Total events: 428 (FP/SAL), 416 (BUD/F) } \\
\hline \multicolumn{6}{|c|}{ Heterogeneity: $\mathrm{Chi}^{2}=0.44, \mathrm{df}=\mid(P=0.5 \mathrm{I}) ; \mathrm{I}^{2}=0.0 \%$} \\
\hline \multicolumn{6}{|c|}{ Test for overall effect: $Z=0.76(P=0.44)$} \\
\hline
\end{tabular}

$\begin{array}{lllllll}0.1 & 0.2 & 0.5 & 1 & 2 & 5 & 10\end{array}$

Favours FP/SAL Favours BUD/F

Analysis I.I7. Comparison I Combination fluticasone/salmeterol versus budesonide/formoterol, Outcome 17 Headache.

Review: Combination fluticasone and salmeterol versus fixed dose combination budesonide and formoterol for chronic asthma in adults and children

Comparison: I Combination fluticasone/salmeterol versus budesonide/formoterol

Outcome: 17 Headache

\begin{tabular}{|c|c|c|c|c|c|}
\hline \multirow[t]{2}{*}{ Study or subgroup } & FP/SAL & $\mathrm{BUD} / \mathrm{F}$ & Odds Ratio & \multirow[t]{2}{*}{ Weight } & \multirow{2}{*}{$\begin{array}{r}\text { Odds Ratio } \\
\text { M-H,Fixed,95\% Cl }\end{array}$} \\
\hline & $\mathrm{n} / \mathrm{N}$ & $\mathrm{n} / \mathrm{N}$ & M-H,Fixed,95\% Cl & & \\
\hline Aalbers 2004 & $9 / 224$ & $4 / 215$ & & $4.2 \%$ & $2.21[0.67,7.28]$ \\
\hline Busse 2008 & $3 / 406$ & $6 / 427$ & & $6.2 \%$ & $0.52[0.13,2.10]$ \\
\hline EXCEL & $101 / 697$ & $95 / 700$ & & $86.5 \%$ & $1.08[0.80,1.46]$ \\
\hline SAM40048 & $2 / 121$ & $3 / 126$ & & $3.1 \%$ & $0.69[0.11,4.20]$ \\
\hline Total (95\% CI) & 1448 & 1468 & 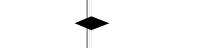 & $100.0 \%$ & $1.08[0.82,1.43]$ \\
\hline \multicolumn{6}{|c|}{ Total events: II5 (FP/SAL), I08 (BUD/F) } \\
\hline \multicolumn{6}{|c|}{ Heterogeneity: $\mathrm{Chi}^{2}=2.66, \mathrm{df}=3(P=0.45) ; \mathrm{I}^{2}=0.0 \%$} \\
\hline \multicolumn{6}{|c|}{ Test for overall effect: $Z=0.54(P=0.59)$} \\
\hline
\end{tabular}

$\begin{array}{lllllll}0.1 & 0.2 & 0.5 & 1 & 2 & 5 & 10\end{array}$

Favours FP/SAL Favours BUD/F 
Analysis I.18. Comparison I Combination fluticasone/salmeterol versus budesonide/formoterol, Outcome 18 Candidiasis.

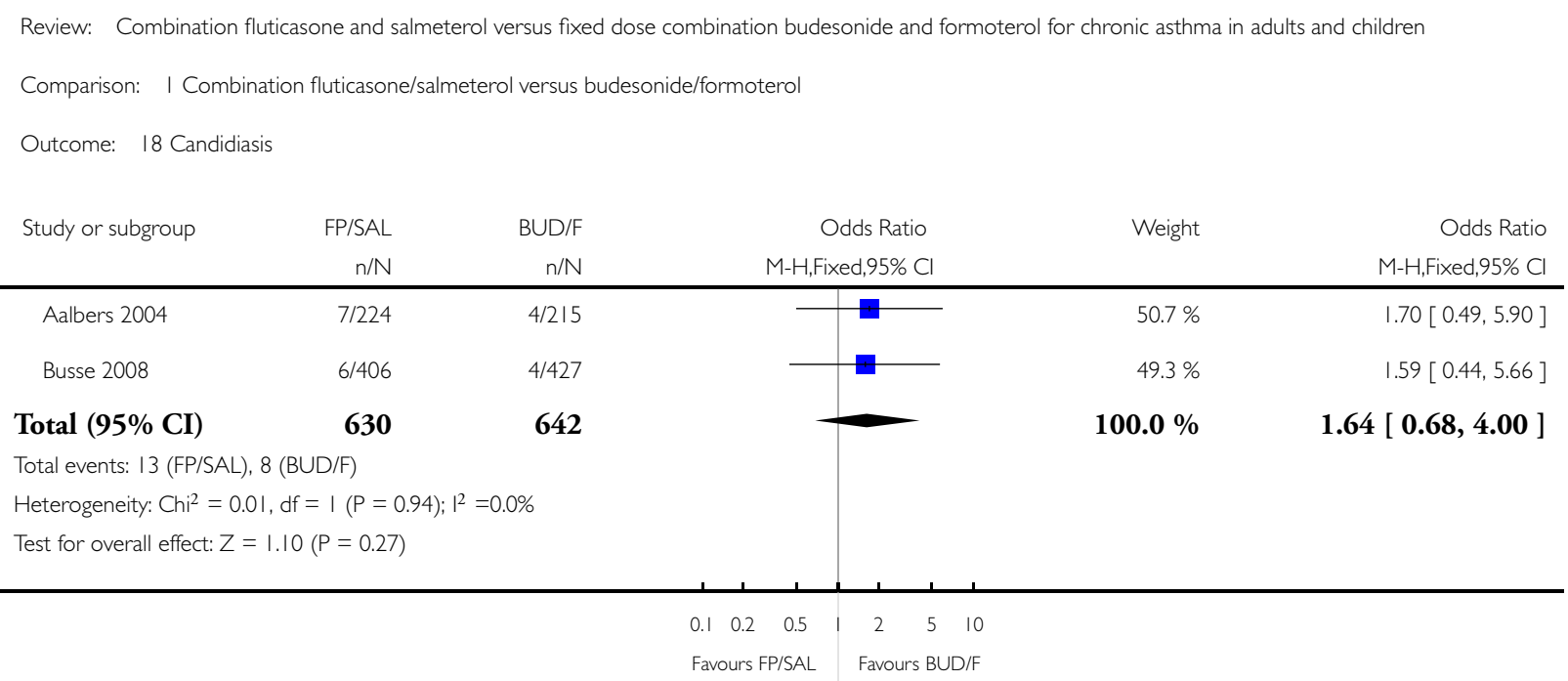

Analysis I.19. Comparison I Combination fluticasone/salmeterol versus budesonide/formoterol, Outcome 19 Dysphonia.

Review: Combination fluticasone and salmeterol versus fixed dose combination budesonide and formoterol for chronic asthma in adults and children

Comparison: I Combination fluticasone/salmeterol versus budesonide/formoterol

Outcome: 19 Dysphonia

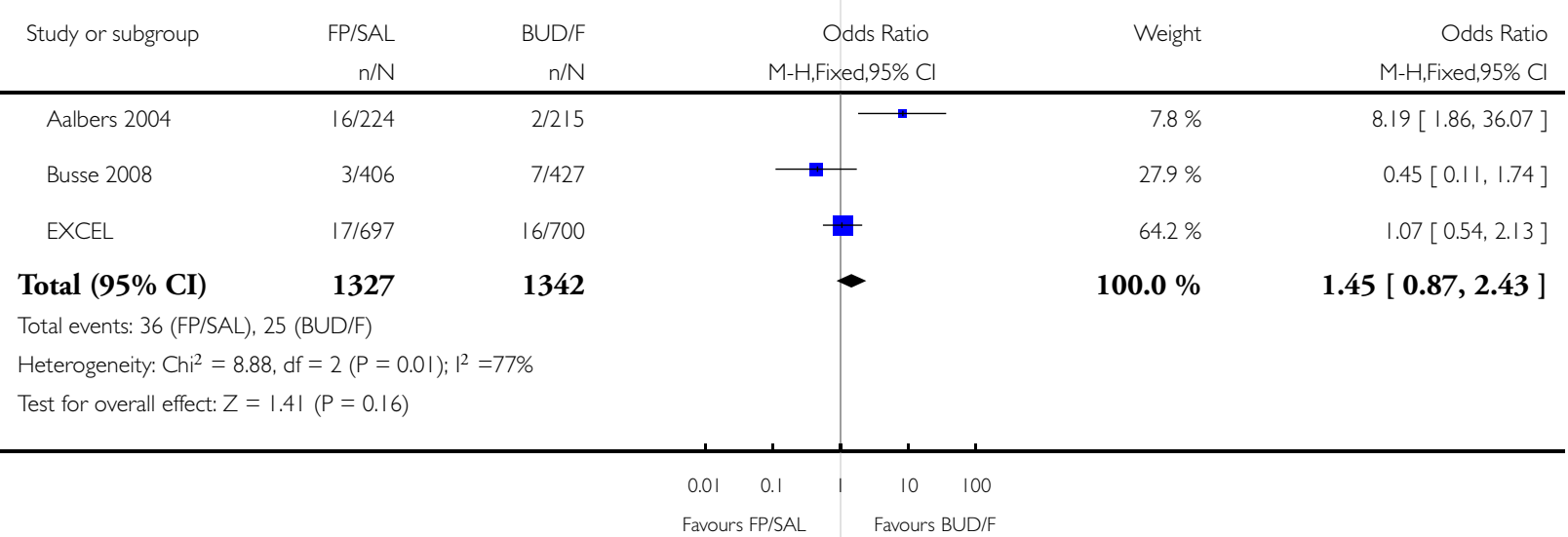


Analysis I.20. Comparison I Combination fluticasone/salmeterol versus budesonide/formoterol, Outcome 20 Upper respiratory tract infection.

Review: Combination fluticasone and salmeterol versus fixed dose combination budesonide and formoterol for chronic asthma in adults and children

Comparison: I Combination fluticasone/salmeterol versus budesonide/formoterol

Outcome: 20 Upper respiratory tract infection

\begin{tabular}{|c|c|c|c|c|c|}
\hline \multirow[t]{2}{*}{ Study or subgroup } & FP/SAL & $\mathrm{BUD} / \mathrm{F}$ & Odds Ratio & Weight & Odds Ratio \\
\hline & $\mathrm{n} / \mathrm{N}$ & $\mathrm{n} / \mathrm{N}$ & M-H,Fixed,95\% Cl & & M-H,Fixed,95\% Cl \\
\hline EXCEL & $101 / 697$ & $94 / 700$ & & $96.5 \%$ & $1.09[0.81,1.48]$ \\
\hline SAM40048 & $3 / 121$ & $3 / 126$ & & $3.5 \%$ & $1.04[0.21,5.27]$ \\
\hline Total (95\% CI) & 818 & 826 & 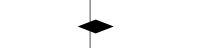 & $100.0 \%$ & $1.09[0.81,1.47]$ \\
\hline \multicolumn{6}{|c|}{ Total events: I04 (FP/SAL), 97 (BUD/F) } \\
\hline \multicolumn{6}{|c|}{ Heterogeneity: $\mathrm{Chi}^{2}=0.00, \mathrm{df}=\mathrm{I}(P=0.96) ; \mathrm{I}^{2}=0.0 \%$} \\
\hline \multicolumn{6}{|c|}{ Test for overall effect: $Z=0.57(P=0.57)$} \\
\hline
\end{tabular}

$\begin{array}{lllllll}0.1 & 0.2 & 0.5 & 1 & 2 & 5 & 10\end{array}$

Favours FP/SAL Favours BUD/F

Analysis I.2I. Comparison I Combination fluticasone/salmeterol versus budesonide/formoterol, Outcome 21 Rhinitis.

Review: Combination fluticasone and salmeterol versus fixed dose combination budesonide and formoterol for chronic asthma in adults and children

Comparison: I Combination fluticasone/salmeterol versus budesonide/formoterol

Outcome: 21 Rhinitis

\begin{tabular}{|c|c|c|c|c|}
\hline \multirow[t]{2}{*}{ Study or subgroup } & FP/SAL & & Odds Ratio & Odds Ratio \\
\hline & $\mathrm{n} / \mathrm{N}$ & $\mathrm{n} / \mathrm{N}$ & M-H,Fixed,95\% Cl & M-H,Fixed,95\% Cl \\
\hline EXCEL & $45 / 697$ & $34 / 700$ & 1 & $1.35[0.85,2.14]$ \\
\hline
\end{tabular}


Analysis I.22. Comparison I Combination fluticasone/salmeterol versus budesonide/formoterol, Outcome 22 Throat irritation.

Review: Combination fluticasone and salmeterol versus fixed dose combination budesonide and formoterol for chronic asthma in adults and children

Comparison: I Combination fluticasone/salmeterol versus budesonide/formoterol

Outcome: 22 Throat irritation

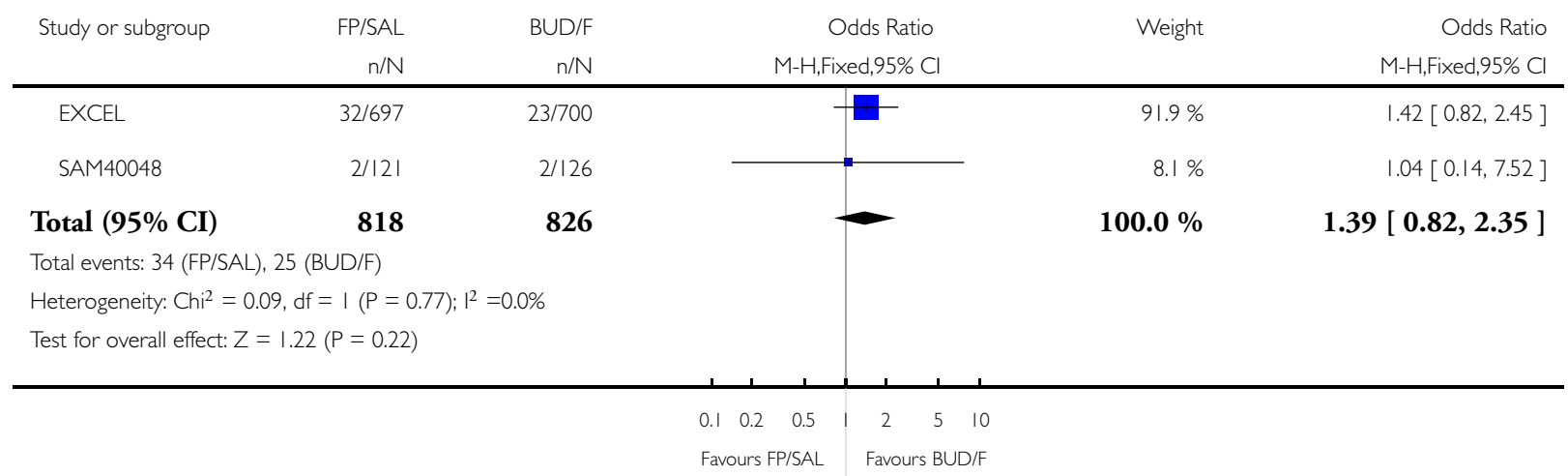

Analysis I.23. Comparison I Combination fluticasone/salmeterol versus budesonide/formoterol, Outcome 23 Cough.

Review: Combination fluticasone and salmeterol versus fixed dose combination budesonide and formoterol for chronic asthma in adults and children

Comparison: I Combination fluticasone/salmeterol versus budesonide/formoterol

Outcome: 23 Cough

\begin{tabular}{|c|c|c|c|c|}
\hline \multirow[t]{2}{*}{ Study or subgroup } & $\mathrm{FP} / \mathrm{SAL}$ & $\mathrm{BUD} / \mathrm{F}$ & Odds Ratio & Odds Ratio \\
\hline & $n / N$ & $n / N$ & M-H,Fixed,95\% Cl & M-H,Fixed,95\% Cl \\
\hline EXCEL & $25 / 697$ & $22 / 700$ & 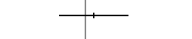 & $1.15[0.64,2.05]$ \\
\hline
\end{tabular}




\section{Analysis I.24. Comparison I Combination fluticasone/salmeterol versus budesonide/formoterol, Outcome}

24 Tremor.

\section{Review: Combination fluticasone and salmeterol versus fixed dose combination budesonide and formoterol for chronic asthma in adults and children}

Comparison: I Combination fluticasone/salmeterol versus budesonide/formoterol

Outcome: 24 Tremor

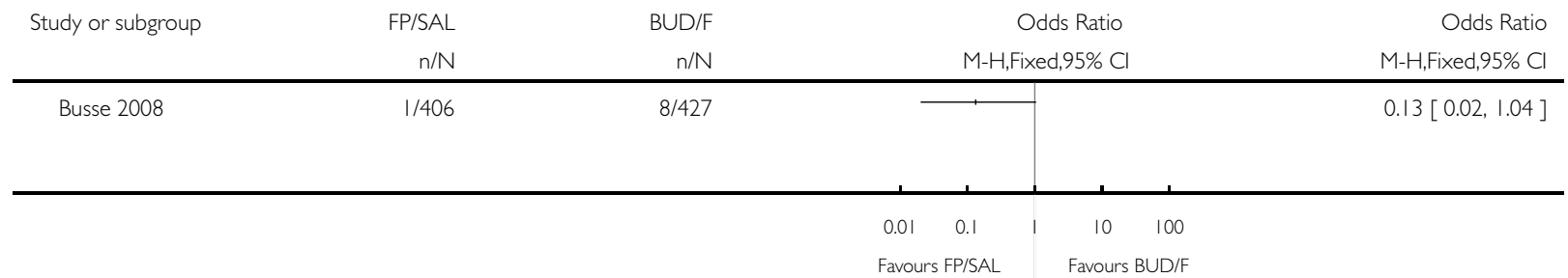

\section{WHAT'S NEW}

Last assessed as up-to-date: 20 January 2010.

\begin{tabular}{lll}
\hline Date & Event & Description \\
\hline 8 May 2009 & New search has been performed & $\begin{array}{l}\text { Literature search re-run: no new studies identified. Risk of bias table completed } \\
\text { and Summary of Findings table added }\end{array}$ \\
\hline
\end{tabular}

\section{H I S T O R Y}

Protocol first published: Issue 1, 2003

Review first published: Issue 3, 2008

\begin{tabular}{lll}
\hline Date & Event & Description \\
\hline 19 June 2008 & Amended & Data from Aalbers 2004 added to the primary endpoint (OCS-treated exacerbations) \\
\hline 13 May 2008 & Amended & Converted to new review format. \\
\hline
\end{tabular}




\section{CONTRIBUTIONSOFAUTHORS}

TJL devised the protocol with editorial support from CJC; Assessed studies, extracted data, contacted trialists and study sponsors for additional outcome data; analysis and write-up

GF developed the protocol; wrote up study characteristics, extracted data and assisted with development of discussion section.

LC developed discussion section.

CJC: helped with data extraction and checking, interpretation and guidance on conceptual issues.

\section{DECLARATIONS OF INTEREST}

There are no known conflicts of interest.

\section{SOURCES OFSUPPORT}

\section{Internal sources}

- No sources of support supplied

\section{External sources}

- NHS Cochrane Collaboration Programme Grant Scheme, UK.

\section{DIFFERENCES BETWEEN PROTOCOLANDREVIEW}

Added items to the risk of bias tool (allocation generation, selective reporting bias $\&$ other bias domains).

\section{NOTES}

A previous version of this review was withdrawn prior to publication following the identification of incomplete data by GSK for the outcome ED visit/admission to hospital. The data included in the original version of the review indicated a significant increase in the odds of ED visit/hospitalisation with FP/SAL. However, this reflected data that were drawn from those participants who were admitted to hospital only. The pooled outcome data did not an accurately represent the composite outcome of presentation at ED or hospital admission (EXCEL). We have now included data made available to us by GSK which are an accurate record of ED visit or admission to hospital.

\section{N DEX TERMS}




\section{Medical Subject Headings (MeSH)}

Albuterol [administration \& dosage; analogs \& derivatives]; Androstadienes [administration \& dosage]; Anti-Asthmatic Agents [*administration \& dosage]; Asthma [*drug therapy]; Budesonide [administration \& dosage]; Drug Combinations; Ethanolamines [administration \& dosage]; Randomized Controlled Trials as Topic

\section{MeSH check words}

Adult; Child; Humans 